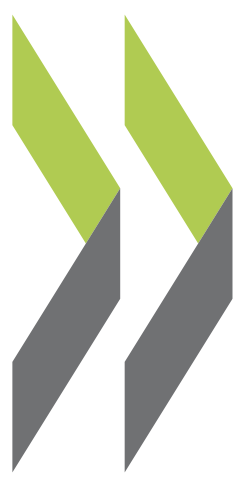

OECD Economics Department Working Papers No. 1405

Raising skills in Portugal Sónia Araújo 
Organisation de Coopération et de Développement Économiques

Organisation for Economic Co-operation and Development

22-Aug-2017

ECONOMICS DEPARTMENT

English - Or. English

\section{RAISING SKILLS IN PORTUGAL}

ECONOMICS DEPARTMENT WORKING PAPERS No. 1405

\section{By Sónia Araújo}

OECD Working papers should not be reported as representing the official views of the OECD or of its member countries. The opinions expressed and arguments employed are those of the author(s).

Authorised for publication by Alvaro Pereira, Director, Country Studies Branch, Economics Department.

All Economics Department Working Papers are available at www.oecd.org/eco/workingpapers

Complete document available on OLIS in its original format

This document, as well as any data and map included herein, are without prejudice to the status of or sovereignty over any territory, to the delimitation of international frontiers and boundaries and to the name of any territory, city or area. 
OECD Working Papers should not be reported as representing the official views of the OECD or of its member countries. The opinions expressed and arguments employed are those of the author(s).

Working Papers describe preliminary results or research in progress by the author(s) and are published to stimulate discussion on a broad range of issues on which the OECD works.

Comments on Working Papers are welcomed, and may be sent to OECD Economics Department, 2 rue André Pascal, 75775 Paris Cedex 16, France, or by e-mail to eco.contact@ oecd.org.

All Economics Department Working Papers are available at www.oecd.org/eco/workingpapers.

This document and any map included herein are without prejudice to the status of or sovereignty over any territory, to the delimitation of international frontiers and boundaries and to the name of any territory, city or area.

The statistical data for Israel are supplied by and under the responsibility of the relevant Israeli authorities. The use of such data by the OECD is without prejudice to the status of the Golan Heights, East Jerusalem and Israeli settlements in the West Bank under the terms of international law.

You can copy, download or print OECD content for your own use, and you can include excerpts from OECD publications, databases and multimedia products in your own documents, presentations, blogs, websites and teaching materials, provided that suitable acknowledgment of OECD as source and copyright owner is given. All requests for commercial use and translation rights should be submitted to rights@oecd.org 
ECO/WKP(2017)37

\section{ABSTRACT/RÉSUMÉ \\ Raising skills in Portugal}

Despite significant progress made, improving skills remains one of Portugal's key challenges for raising growth, living standards and well-being. Upskilling the adult population remains a priority and lifelong learning activities should focus more on the low skilled. While active labour market policies have increased their training content in recent years, spending per unemployed is still low. A systematic monitoring of the different programmes would allow concentrating resources on the policies that are more effective in raising skills and employment prospects. In the education system, successive increases in compulsory education have not eliminated early school leaving, and a significant share of youth is left without completed secondary education, thus facing poor labour market prospects and a risk of falling into poverty. Another challenge for the education system is to reduce the link between learning outcomes and socio-economic backgrounds. This could be achieved by providing earlier and individualised support to students at risk of falling behind, strengthening teachers and principals training and exposure to best practices, and creating incentives to attract the more experienced teachers to disadvantaged schools. Vocational education and training (VET) has received less attention than general education until recent years and has suffered from fragmented management. This has curtailed the employment prospects of youth not wishing to pursue tertiary education. Establishing a single VET system and reinforcing work-based learning in companies would address this issue. Tertiary education has expanded considerably over recent years but could have a stronger focus on labour market needs, including by developing tertiary technical education. Enhanced support for business research activities could be coupled with strengthening management skills and the ties between businesses and researchers, for example by creating incentives for academics to cooperate with the private sector.

This Working Paper relates to the 2017 OECD Economic Survey of Portugal

(www.oecd.org/eco/surveys/economic-survey-portugal.htm).

JEL: I24, I25, I28, J24.

Keywords: Portugal, Skills, Education System, Vocational Education and Training, Adult Education and Training, Youth Unemployment, Labour Market Segmentation; Managerial Skills.

\section{Renforcer les compétences au Portugal}

Malgré de réels progrès, le renforcement des compétences reste l'un des principaux défis que le Portugal doit relever s'il veut améliorer la croissance, les niveaux de vie et le bien-être. Le développement des compétences des adultes demeure une priorité et les activités de formation tout au long de la vie devraient cibler davantage les adultes peu qualifiés. Le volet formation des politiques actives du marché du travail s'est développé ces dernières années, mais le budget par demandeur d'emploi reste faible. Un suivi systématique des différents programmes permettrait de concentrer les ressources sur les mesures les plus efficaces pour améliorer les compétences et les perspectives d'emploi. Au sein du système éducatif, les hausses successives au niveau de la scolarité obligatoire n'ont pas permis d'éliminer l'abandon scolaire précoce, et de nombreux jeunes se retrouvent sans diplôme secondaire et sont donc confrontés à des perspectives d'emploi médiocres et au risque de tomber dans la pauvreté. Le système éducatif doit également parvenir à réduire le lien entre résultats scolaires et milieu socioéconomique d'origine. Il faudrait pour cela proposer un soutien plus précoce et plus individualisé aux élèves en difficulté, renforcer la formation des enseignants et des chefs d'établissement et les sensibiliser davantage aux meilleures pratiques, et mettre en place des incitations pour attirer les enseignants les plus expérimentés dans les établissements scolaires défavorisés. Le système d'enseignement professionnel n'avait pas, jusqu'à une date récente, bénéficié de la même attention que l'enseignement général et souffre d'une gestion morcelée, ce qui n'améliore pas les perspectives professionnelles des jeunes qui ne souhaitent pas poursuivre des études supérieures. La mise en place d'un système d'enseignement professionnel unique et le renforcement des possibilités de formation en entreprise permettraient d'améliorer la situation. L'enseignement supérieur s'est considérablement développé ces dernières années, mais il pourrait mieux prendre en compte les besoins du marché du travail, notamment en développant les cursus techniques. Le soutien accru aux activités de recherche des entreprises pourrait s'accompagner d'un renforcement des aptitudes en matière de gestion ainsi que des liens entre les entreprises et les chercheurs, par exemple en incitant les universitaires à coopérer avec le secteur privé.

Ce Document de travail se rapporte à l'Étude économique de l'OCDE du Portugal 2017

(http://www.oecd.org/fr/economie/etude-economique-portugal.htm)

JEL: I24, I25, I28, J24.

Mots clés: Portugal, compétences, système d'éducation, enseignement et formation professionnels, éducation et formation des adultes, chômage des jeunes, segmentation du marché de travail, compétences de gestion. 


\section{TABLE OF CONTENTS}

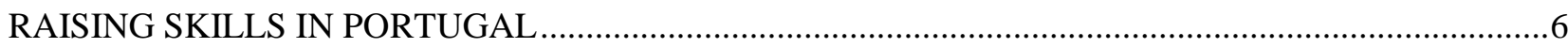

Low skills are obstacles to improvements in growth and well-being ......................................................6

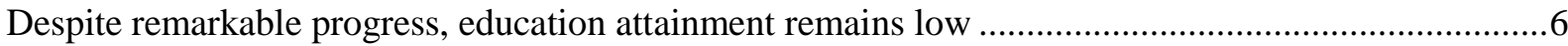

Labour market incentives for upskilling could be stronger ..................................................................

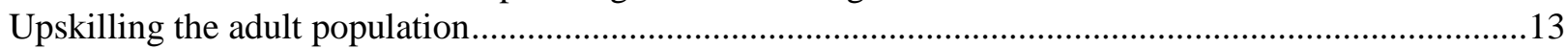

Target adult education and lifelong learning towards the low skilled................................................13

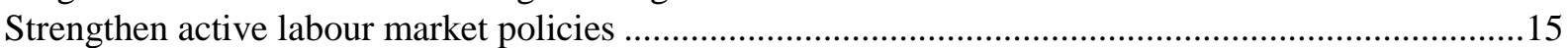

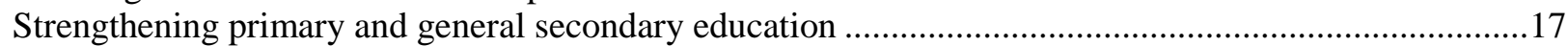

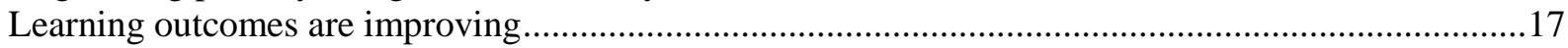

The education system needs to do more to reach to disadvantaged children ........................................18

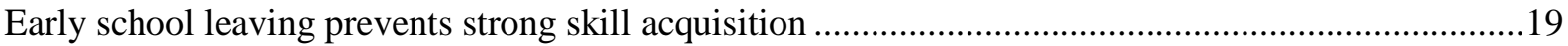

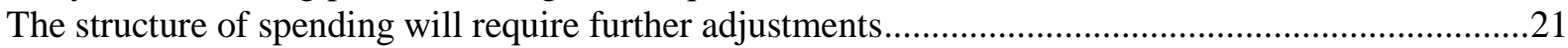

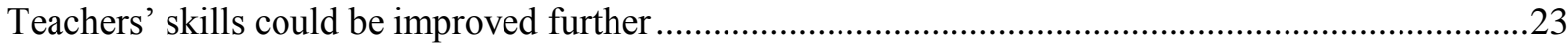

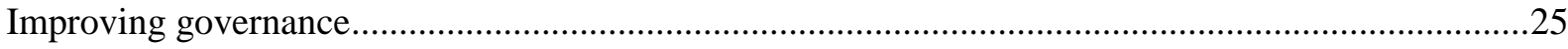

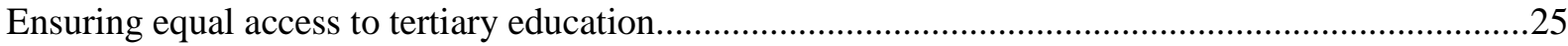

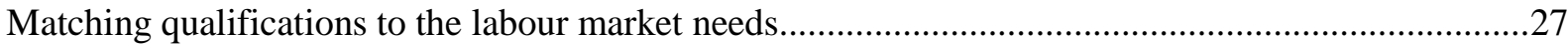

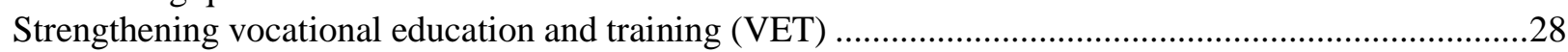

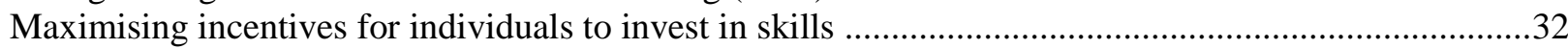

Labour market segmentation reduces incentives for individuals to invest in skills ...............................32

Low managerial skills are holding back the potential contributions of high-skilled professionals.........33

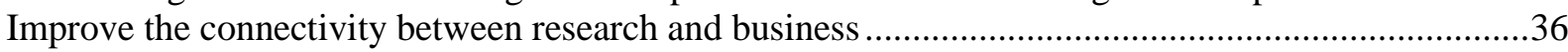

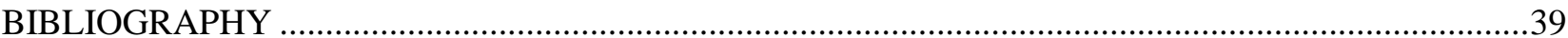

\section{Tables}

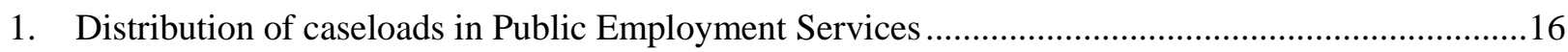

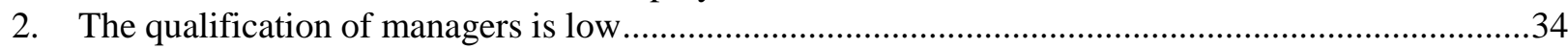

\section{Figures}

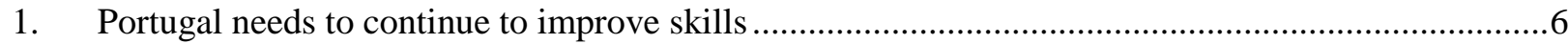

2. Education attainment has improved but private returns remain high ..............................................

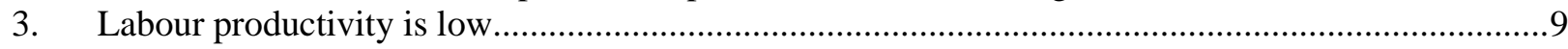

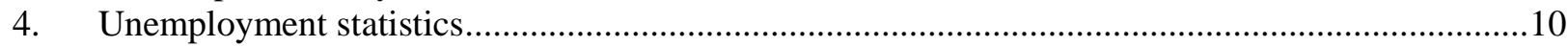

5. Skills are facing rising demand and improve workers' labour market prospects ...........................11

6. Labour market segmentation disproportionally affects the young ...............................................12

7. More effort needs to be put in upskilling the labour force ........................................................... 14

8. Structure of public spending on active labour market programmes (ALMP) ................................15

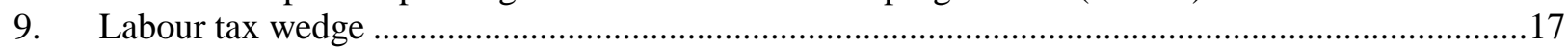




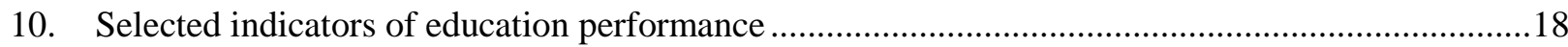

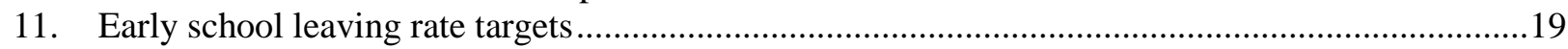

12. Grade repetition is too commonly used and entails high costs .....................................................20

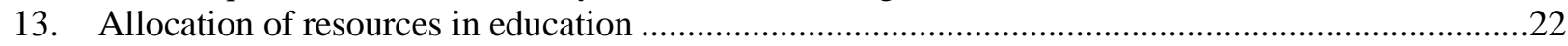

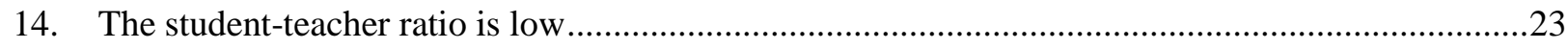

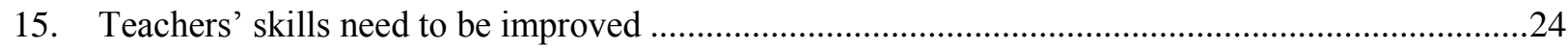

16. Relationship between students' participation in higher education and socio-economic status ........26

17. Average returns to costs ratio of government investment in university education ...........................27

18. Matching enrolment to the labour market needs improvement ................................................28

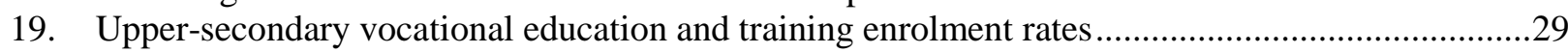

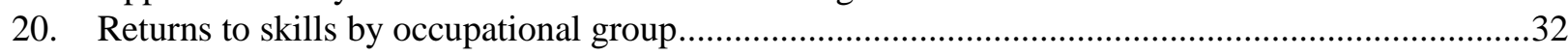

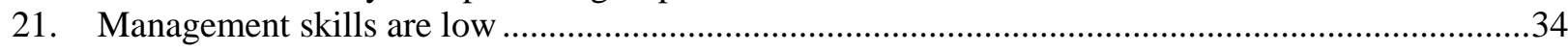

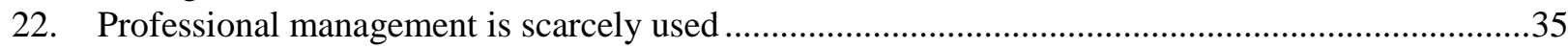

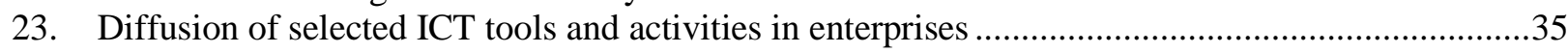

24. Doctorate holders work primarily in the education sector .............................................................37

25. Only a small share of SMEs collaborates on innovation with higher education or research institutions

\section{Boxes}

Box 1. The Portuguese Education System: Main characteristics..........................................................6

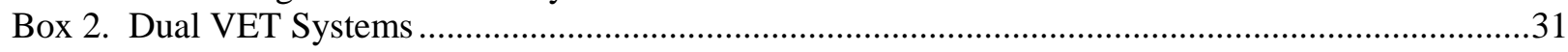

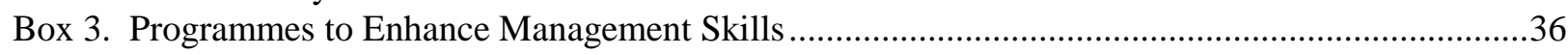

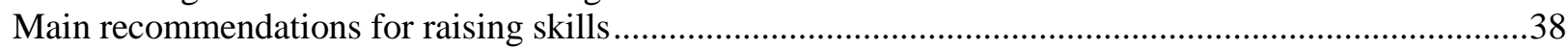




\title{
RAISING SKILLS IN PORTUGAL
}

\author{
By Sónia Araújo
}

\section{Low skills are obstacles to improvements in growth and well-being}

\section{Despite remarkable progress, education attainment remains low}

Educational attainments and skills of Portugal's population are low in international comparison. Only $43 \%$ of the working age population (25-64 years old) has completed secondary education, in sharp contrast with the OECD average of $76 \%$ (Figure 1). Even lower secondary education, which corresponds to nine years of schooling in Portugal, has been completed by only $64 \%$ of the working age population, less than in any OECD country except for Mexico and Turkey (Box 1; OECD, 2016a).

Figure 1. Portugal needs to continue to improve skills

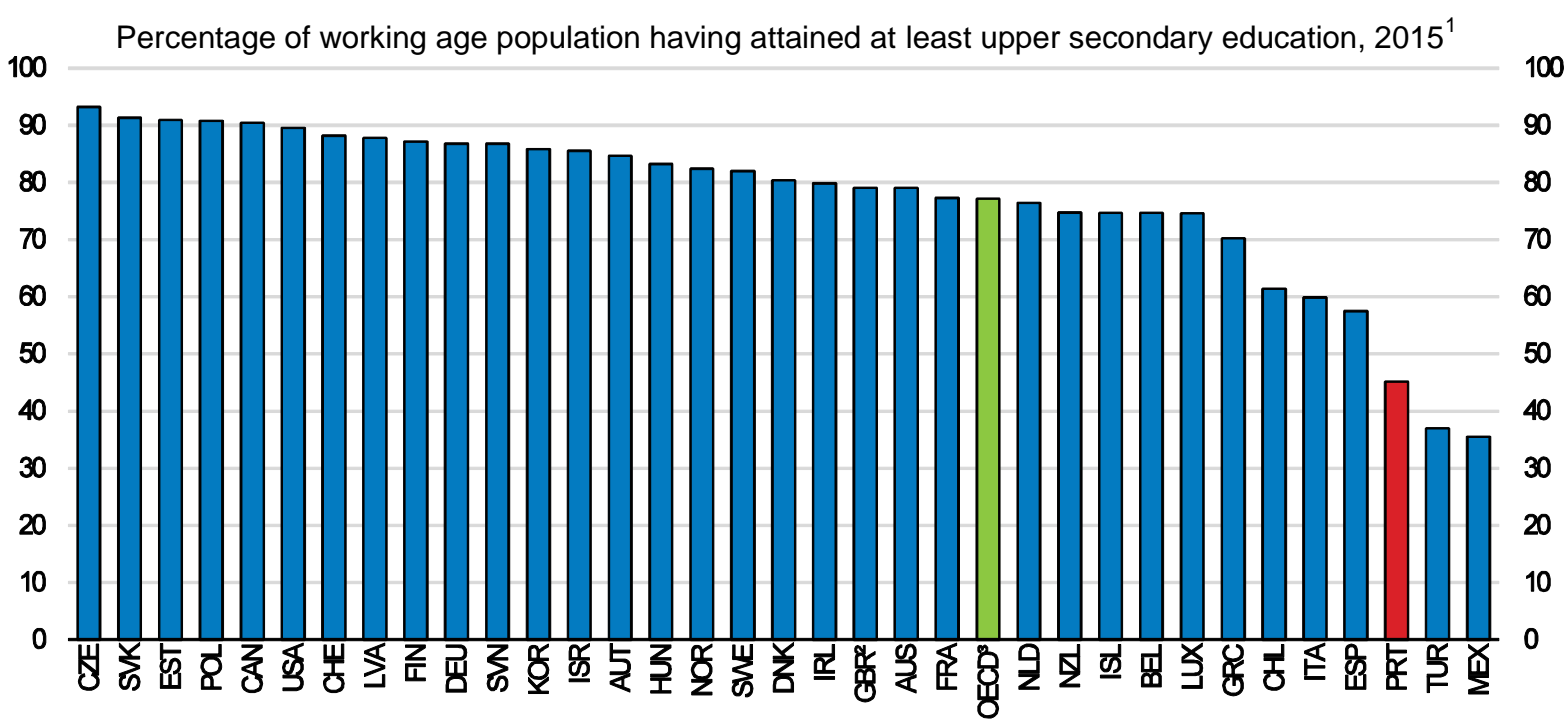

1. Working age population: 25-64 year- olds. 2013 for Chile and 2014 for France.

2. Includes completion of a sufficient volume and standard of programmes that would be classified individually as completion of intermediate upper secondary programmes (18\% of the adults are under this group).

3. Unweighted average of data shown including Latvia.

Source: OECD (2016a), Education at a Glance 2016: OECD Indicators. ${ }^{1}$

\section{Box 1. The Portuguese Education System: Main characteristics}

The Portuguese Education System is articulated between the Ministry of Education and the Ministry of Science, Technology and Higher Education, who have the responsibility of defining, co-ordinating, implementing and evaluating education policies. The school system is organised in three sequential levels: pre-primary education (ages 3 to 5), basic education (ages 6 to 14) and secondary education (typical ages 15 to 18). Compulsory education begins at age 6 and ends at age 18 or upon completion of secondary education.

1. Sónia Araújo is a senior economist in the OECD Economics Department. The author is grateful to Pierre Beynet, Robert Ford, Álvaro Pereira, Jens Arnold, Paulo Santiago, Cláudia Sarrico and Muge Adelet McGowan for valuable comments and suggestions on earlier drafts, as well as for discussions with Portuguese officials. Special thanks go to Daniela Crosera for research assistance, Desney Wilkinson-Erb for statistical assistance and to Sylvie Ricordeau for editorial assistance. 
There is a public and a private network of pre-primary education institutions. The public network comprises education institutions under the Ministry of Education and the Ministry of Labour, Solidarity and Social Security. The private network included for-profit and non-profit education institutions but the Ministry of Education is responsible for ensuring the pedagogical quality of teaching in pre-primary education institutions network. Secondary education is organised according to strands, with courses that are geared to working life or the continuation of studies in tertiary education. It currently includes: science-humanities courses, geared towards further study at higher education level, covering four areas (science and technology, social and economic sciences, languages and humanities and visual arts); technological courses, geared towards either entry the labour market or further study, especially via postsecondary technological specialisation courses and higher education courses specialised artistic courses; and vocational courses, geared towards an initial qualification of pupils, giving priority to their entering in the job market.

Public school is dominant, with $80 \%$ of the student population attending public schools. Public schools receive funding for the majority of their expenses directly from the State budget, raising complimentary revenues by providing services to the community and through donations. The Ministry of Science, Technology and Higher Education is responsible for the funding of Higher Education.

School governance is fairly centralised. The main decisions about the curriculum, the educational programmes, national examinations, teacher recruitment and deployment and the budget distribution are defined centrally by the Ministry of Education (Santiago et al, 2012). Five regional education authorities are responsible for co-ordinating policy implementation within their respective territories. Over time there has been some decentralisation as municipalities have been granted some responsibilities, although mainly in basic education. Other relevant stakeholders include the National Agency for Qualification (ANQ), which co-ordinates the implementation of vocational education and training and manages the National System of Qualifications; the National Education Council (CNE), an independent body which forms views across the whole range of educational issues by its own initiative or following a request from the government or the Parliament; the Schools Council, representing the viewpoint of schools; parents' organisations and the National Association of Portuguese Municipalities whose views are typically heard. The rate of teacher unionisation is quite high (around two-thirds of teachers), and there is a legal obligation to consult teachers' unions on matters that relate to teachers' working conditions.

Although the budget of the Ministry of Education was the one most severely hit by the adjustment process - having shrunk from 5.6\% of GDP in 2009 to $4.9 \%$ of GDP in 2012 - this contraction was mostly due to fiscal consolidation measures that reduced public sector wages, as expenditures with staff represent about $80 \%$ of the Ministry of Education budget (CNE, 2015).

Sources: Santiago et al (2012), Eurydice (2016), CNE (2015) and CNE (2016).

A major handicap for Portugal has been the very low starting point in terms of educational attainment and literacy of its population. In the mid-1970s a fifth of all 15- to 64- year olds were illiterate and less than 5\% had completed upper secondary education (OECD, 2006; Guichard and Larre, 2006). Continued efforts to ensure access to education for nearly four decades have led to a rapid expansion of attainment. Among OECD countries, Portugal has achieved the second highest increase in education attainment between generations, after Korea: while only $23 \%$ of those aged 55 to 64 attained at least upper secondary education, this rate jumps to 65\% among 25-34 years old (Figure 2, Panel A; OECD, 2015a). Over time, the youngest generation enters the labour market with more qualifications than their predecessors (Figure 2, Panel C). 
Figure 2. Education attainment has improved but private returns remain high

A Younger adutts aged 25-34 having attained at least upper secondary education As a percentage of population in the same age group, 20151

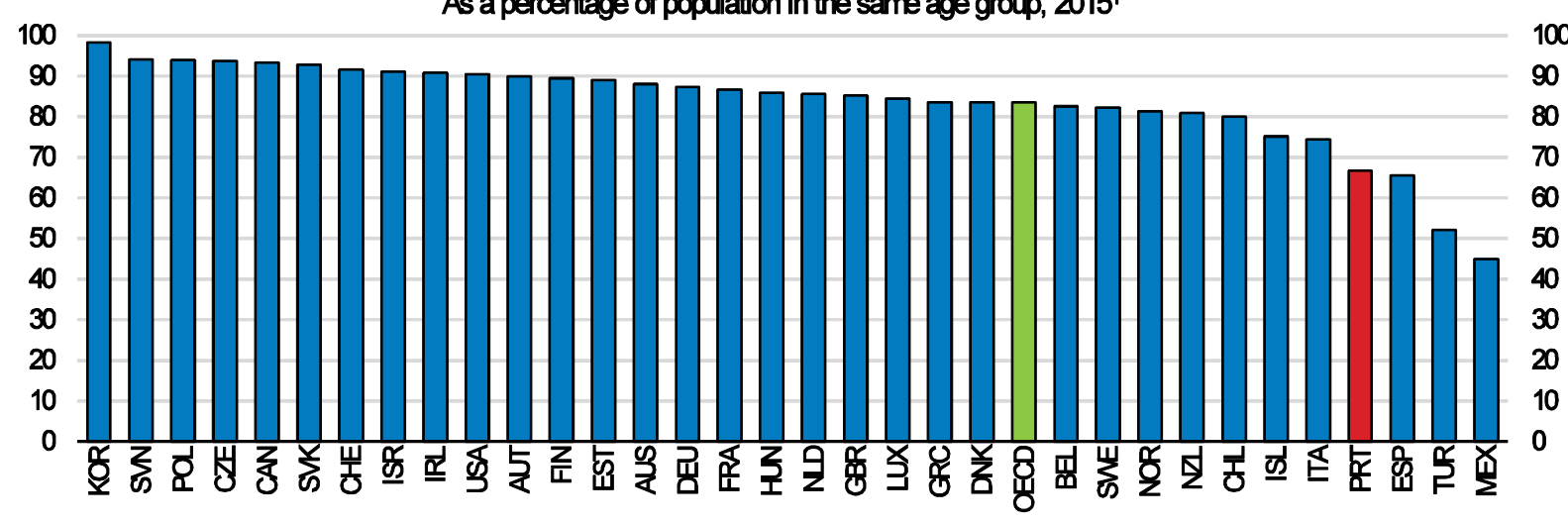

B. Older adults aged 5564 having attained at least upper secondary education

As a percentage of population in the same age group, $2015^{1}$

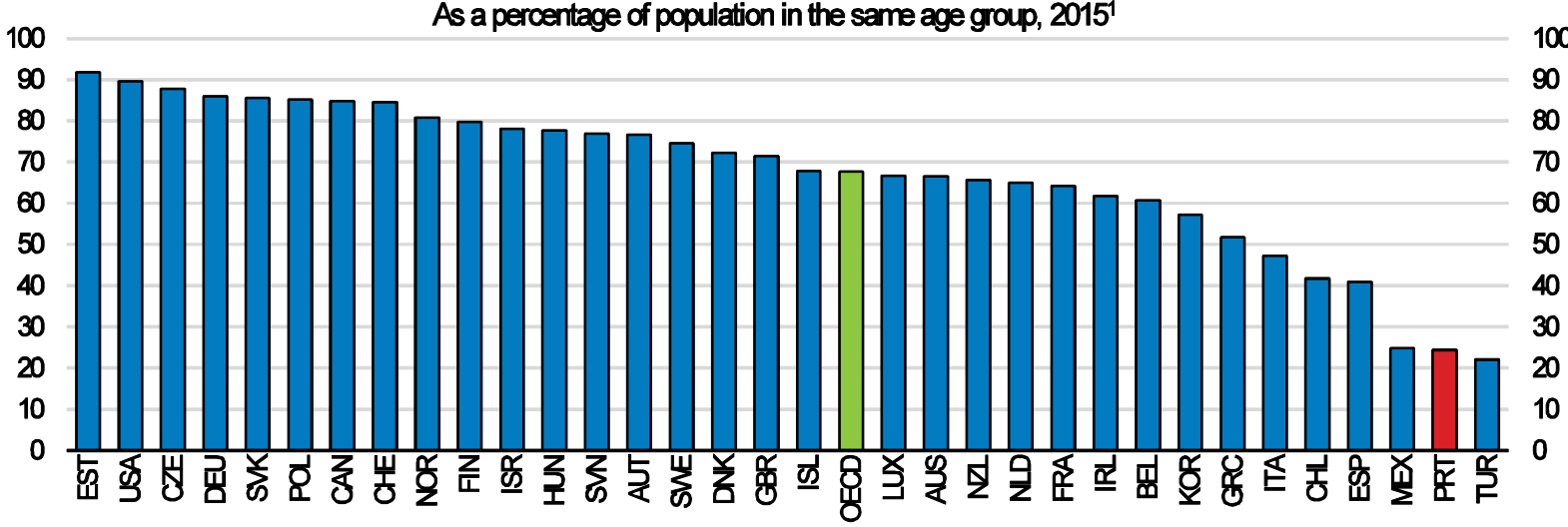

\section{Educational attainment of 25-34 year-olds Percent}

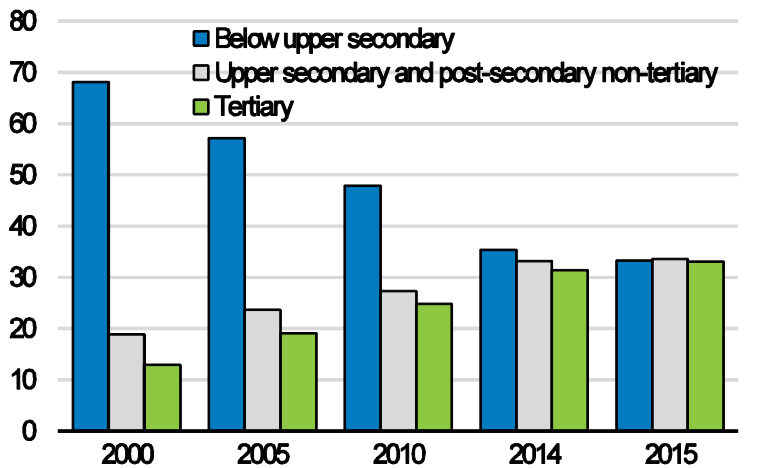

D. Internal rate of return of a person attaining tertiary education Per cent, $2012^{2}$

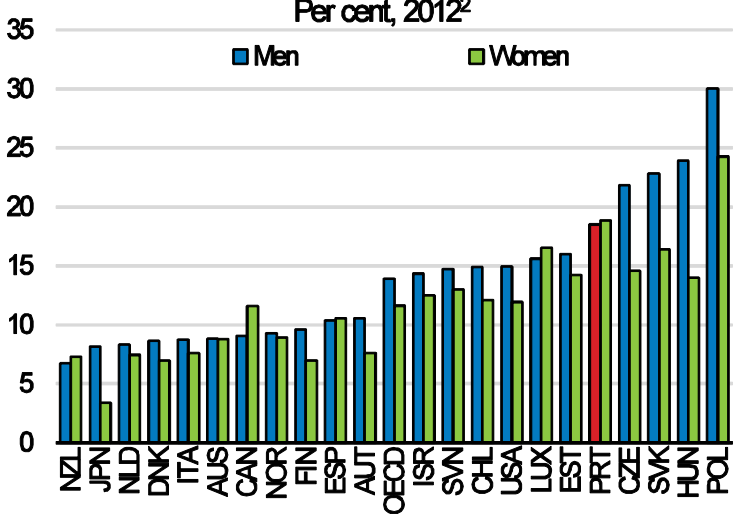

1. The OECD aggregate is an unweighted average of the data shown including Latvia.

2. As compared with a person attaining upper secondary or post-secondary non-tertiary education, in equivalent US dollars converted using purchasing power parities for GDP. The internal rate of return indicates at what real interest rate the investment breaks even. 2010 for Austria, the Netherlands, Norway and Portugal. 2011 for Chile, the Czech Republic and Italy.

Source: OECD (2016a), Education at a Glance 2016: OECD Indicators.

Despite this progress, attainment remains a challenge and low qualifications are not restricted to those who left the education system long ago. Looking only at young adults, the share of those who have completed upper secondary education $(65 \%)$ is the third lowest in the OECD and significantly below the OECD average of $83 \%$ (Figure 2, Panel A). Only $31 \%$ of young adults hold a tertiary degree, contrasting 
with an OECD average of $41 \%$ (Figure 2, Panel B), even though the private returns of tertiary education are comparatively high (Figure 2, Panel D).

Low levels of skills are an obstacle to higher productivity and material living standards, which are low relative to OECD or EU averages. Much of this can be traced back to Portugal's low labour productivity (Figure 3). This reflects large gaps in human capital, but also in multi-factor productivity. But low skills also affect the well-being of Portuguese citizens and stand in the way of reducing income inequality, as education is often a prerequisite for higher job quality and earnings opportunities. Going forward, increasing digitalisation and a higher importance of knowledge are expected to raise returns to skills further (Braconier et al, 2014). This is an important concern for Portugal, which has one of the most unequal income distributions in Europe (Arnold and Farinha Rodrigues, 2015; OECD, 2014a).

Figure 3. Labour productivity is low

Gap with respect to the United States, per cent, $2014^{1}$

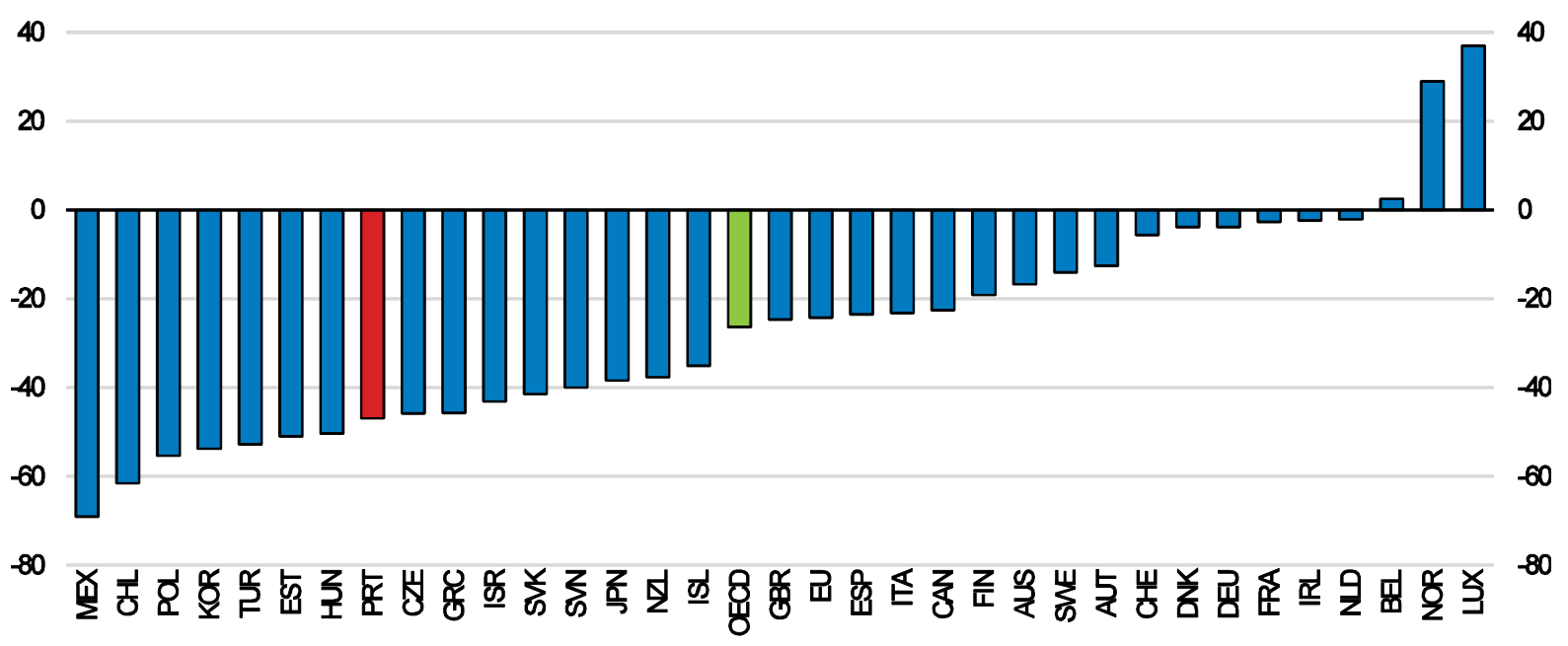

1. Labour productivity is measured by GDP per hour worked.

Source: OECD (2016b), "GDP per capita and productivity levels", OECD Productivity Statistics (database).

\section{Labour market incentives for upskilling could be stronger}

The relationship between skills and the performance of labour markets has elements of a vicious circle. On one hand, low levels of skills reduce the employment prospects for many of Portugal's low skilled workers and improving skills is a key element of policy efforts to reduce unemployment, both present and future. On the other hand, the labour market could offer more in terms of rewards for better skills, which curtails the incentives for individuals to acquire more skills.

At $10.5 \%$, Portugal's unemployment rate is one of highest in the OECD (Figure 4, Panel A). Around one-fifth of the economically active young population is unemployed and long-term unemployment is the fourth highest in the EU, with about $60 \%$ of job-seekers being unemployed for more than a year (Figure 4, Panels B and C). Given that the share of those unemployed for longer than a year has stayed above $40 \%$ for more than a decade now, it appears that a high share of Portugal's unemployment is structural. Long unemployment spells are particularly harmful for youths, as they increase the probability of unemployment throughout most of the working age and increase the chance of dropping out of the labour market altogether (Schmillen and Umkehrer, 2013). 
Figure 4. Unemployment statistics

Per cent, age 15-64
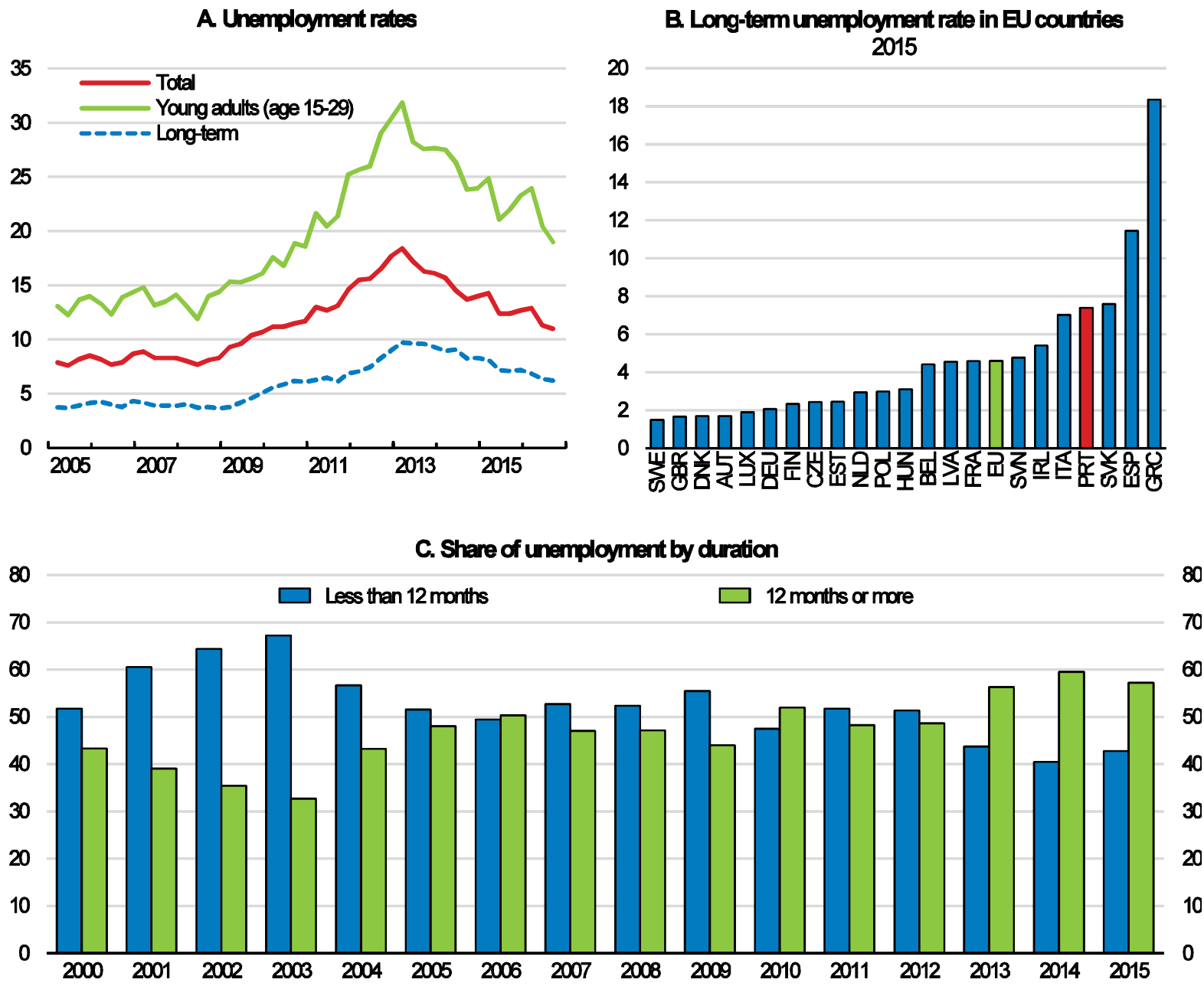

1. For Portuguese data there are breaks in series in 2002, 2005 and 2011. Long-term unemployment is defined as unemployment lasting 12 months or more.

Source: Eurostat (2016), "LFS series - detailed quarterly/annual survey results", Eurostat Database.

Ongoing shifts in the occupation structure of the labour force signal an increasing demand for individuals with a higher education degree (Figure 5, Panel A). In 2010, managers, professional and technicians were the largest job category and their share has increased over recent years, although the rebalancing of the economy towards tradable sectors has also raised demand for plant and machine operators and assemblers (Figure 5, Panel B). Against the backdrop of these developments, those with low qualifications face poor labour market prospects. Indeed, unemployment is lower among tertiary graduates and wage premiums for tertiary education are sizeable (Figure 5, Panels C and D).

Still, it is unclear to what extent the observed differences in unemployment and wages provide sufficiently powerful incentives for investing in skills. Given the high unemployment, labour market prospects for young people are dire and job quality is low with respect to all three dimensions assessed by the OECD: earnings quality, job security and quality of the working environment (OECD, 2016c). The crisis is only partly to blame as job quality was already relatively poor before the crisis. Average hourly 
earnings remain among the lowest in the OECD. While quality of the working environment improved slightly for those people still employed, labour market security fell sharply due to high unemployment (OECD, 2016c).

Figure 5. Skills are facing rising demand and improve workers' labour market prospects
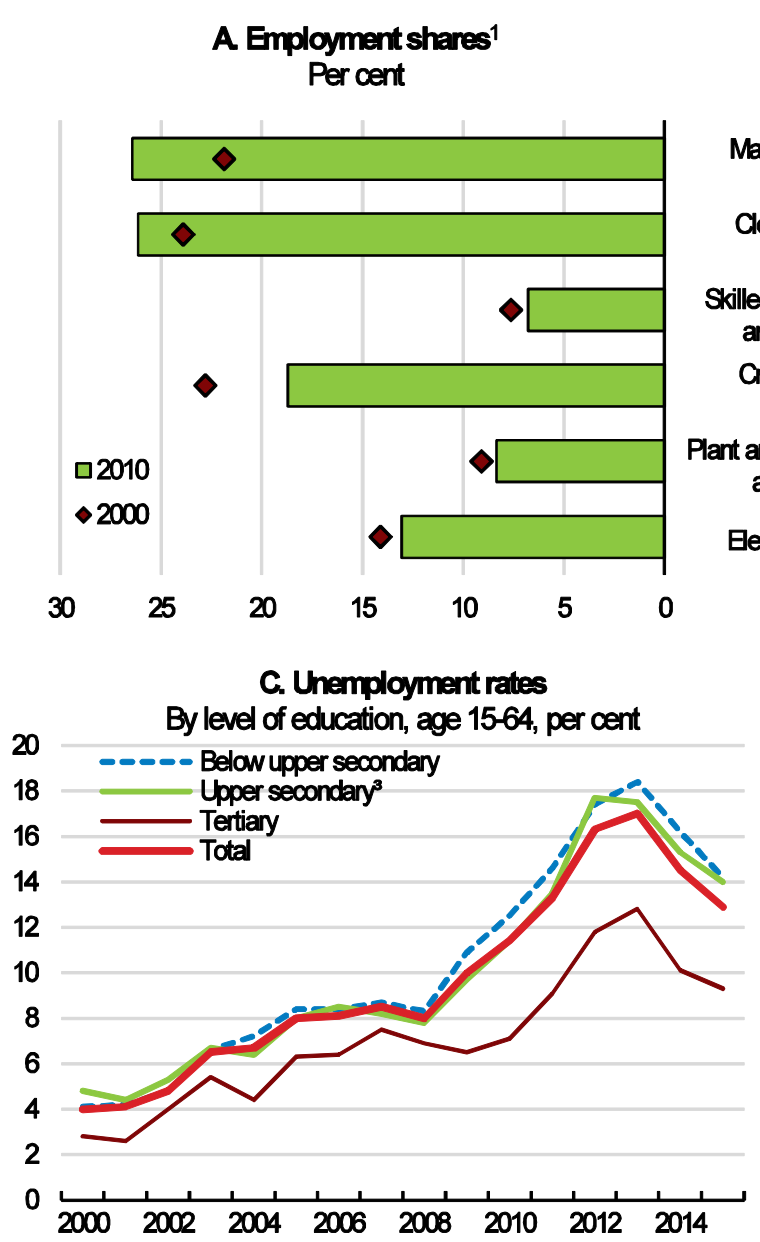

\section{B. Change in employment shares ${ }^{1}$} Percentage points, 2011-15

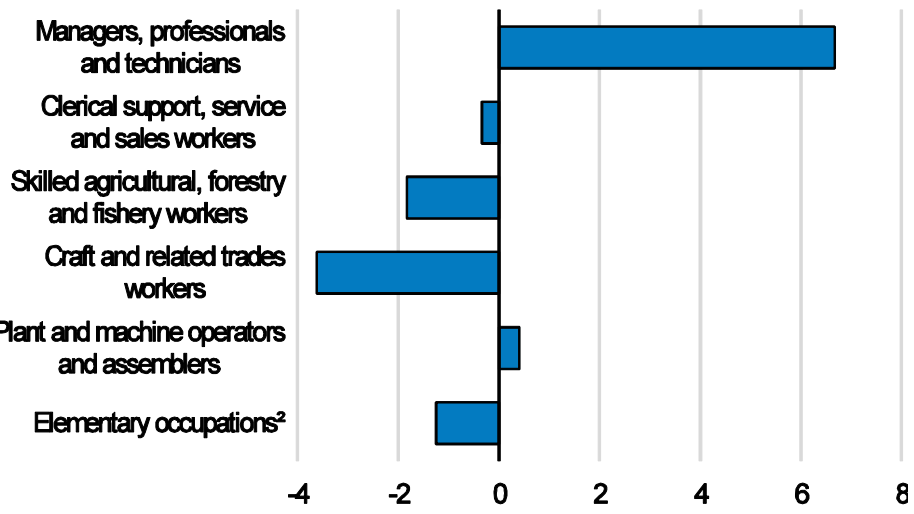

D. Average monthly earnings 4

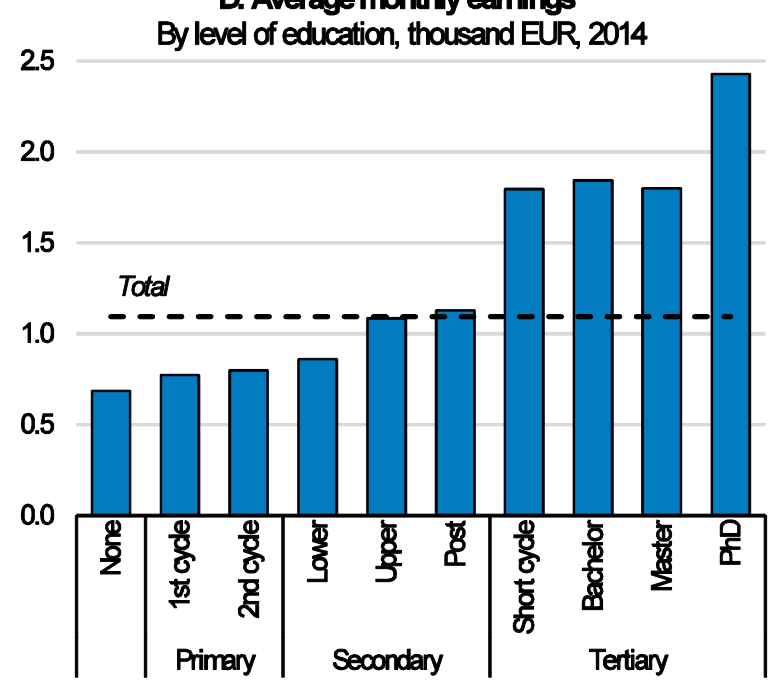

1. Refers to population aged between 15 and 64 .

2. "Elementary occupations" is the title of major group 9 in ISCO. It comprises occupations such as: street vendors, shoe cleaners, domestic helpers, building caretakers, messengers, doorkeepers, garbage collectors, hand labourers, etc.

3. Includes post-secondary non-tertiary education.

4. Regular net amounts in cash or in kind paid to full-time employees for work during normal working hours and overtime, including payment of hours paid but not worked (e.g. holidays).

Source: Eurostat (2016), "LFS series - Detailed annual survey results", Eurostat Database.

Moreover, a highly segmented labour market, including for those aged 25-49, significantly curtails the prospects for young graduates to obtain a stable employment, and higher education attainment also does not increase the likelihood of having a permanent contract relative to secondary education (Figure 6, Panels A and B). Besides excessive use of temporary contracts, disguising dependent employment as selfemployment is another facet of labour market segmentation that puts many workers in a very vulnerable position vis-à-vis their employer. The official share of self-employment is surprisingly high in Portugal (Figure 6, Panel C), which has triggered recent measures to increase the effectiveness of labour 
inspections. Improving the functioning of the labour market through institutional reforms can improve the incentives for investing into skills and although Portugal has embarked on important labour market reforms in recent years, there are important rigidities that still need to be addressed.

Figure 6. Labour market segmentation is high

Per cent, age 15-64, 2015
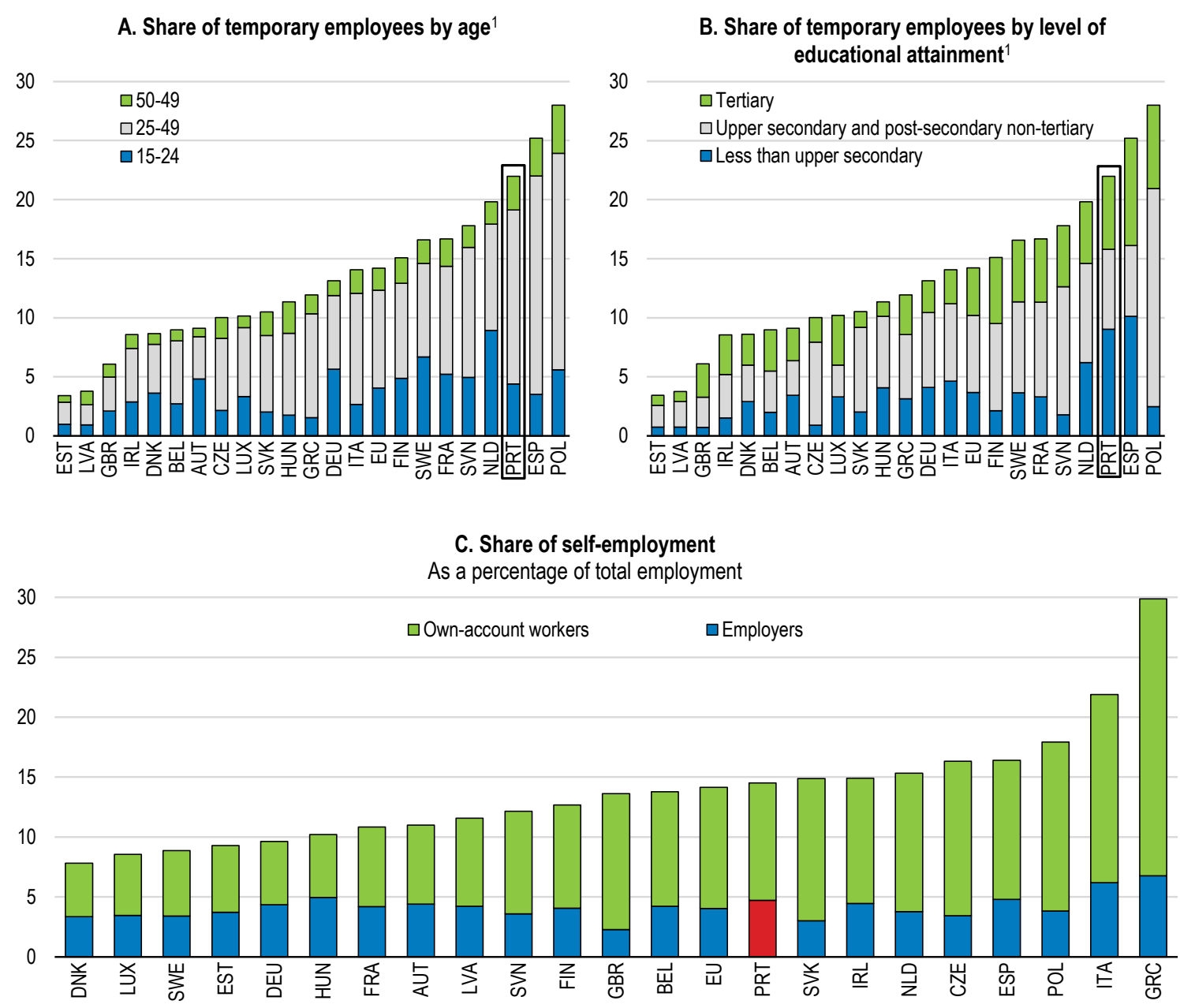

1. Data is calculated as a percentage of employees in each category weighted by the share of that category in total employees.

Source: Eurostat (2016a), "LFS series - detailed annual survey results", Eurostat database and OECD (2016d), OECD Employment and Labour Market Statistics (database).

Against this background, this chapter will discuss policy options to foster skill acquisition among the adult population. This includes young adults, who will be in the workforce for many years to come, but also the long-term unemployed and those that are neither in employment, education or training (NEETs). Active labour market policies are a key policy instrument to support these groups, as they can provide training and support for finding a job. The chapter will also discuss how future education policies should be designed to deliver strong skills and reduce inequities, including by limiting the number of those that leave the education system without at least completing secondary education. Vocational training can play a key role in this respect, smoothing the transition to the labour market for those that do not pursue tertiary education studies. Finally, this chapter will also discuss demand side policies that can foster the creation of high quality jobs for well-skilled Portuguese citizens. The skill challenges highlighted in this chapter are similar to those identified in the 2015 OECD Skill Strategy Diagnostic Report of Portugal (OECD, 2015a). 
ECO/WKP(2017)37

\section{Upskilling the adult population}

\section{Target adult education and lifelong learning towards the low skilled}

Owing to the legacy of Portugal's low educational attainments and given that most of the population has already left the formal education system, improving the skills of the current adults is the most effective way to improve skills without waiting for a generational shift. Adult education has been a policy priority for a number of years and is provided through three main schemes. The Adult Education and Training Courses (Cursos de Educação e Formação de Adultos, EFA) target people over the age of 18 who have not attained the level of upper secondary education, including those with no working experience. All EFA courses involve general and technological education. Certified Modular Training Courses (Formações Modulares Certificadas, FMC) are available to adults who are not interested in taking a full qualification programme. FMC allow flexible, gradual training and are often the opportunity for individuals to increase their knowledge in a field that they are already familiar with. Portugal has also introduced a "Basic Skills Programme" targeted towards the acquisition of basic skills (literacy, numeracy and ICT) in order to enter an EFA course or a process of recognition, validation and certification of competences acquired through labour market experience (Reconhecimento, Validação e Certificação de Competências, RVCC).

The New Opportunities Initiative, launched in December 2005, was a large governmental programme aiming at massively upgrading and upskilling the qualifications of the Portuguese population. It provided low-qualified workers a formal recognition of formal and non-formal qualifications acquired through the working life (RVCC). This process was complemented by formal learning of $4^{\text {th }}, 9^{\text {th }}$ and $12^{\text {th }}$ grades education or/and vocational certification. The program was very ambitious, and by 2010 , over half a million adults had obtained a certification. This number amounts to one sixth of the 3 million Portuguese adults who had still not attained secondary education. The New Opportunities Initiative was discontinued in 2013 and the financial resources devoted to adult education were reduced, which contributed to a sharp decline in enrolments in the RVCC scheme, but also in EFA and FMC training courses (OECD, 2015a). There is little evaluation of the impact of adult education programmes on labour market outcomes. Earlier studies suggest that RVCC and EFA courses have a positive impact on employability and wages, especially among some vulnerable groups in the labour market, such as women and those living in lowincome households (CIDEC, 2004, 2007; Carneiro, 2011). More recent evaluation seems to indicate that, with the exception of FMC courses, adult education training courses have positive employment effects only several years after participation, while there is no evidence of an impact on participants' wages (Costa Dias and Varejão, 2012; Lima, 2012). The RVCC processes have improved employability prospects but only when workplace competencies were validated or the process of validation was linked to training through FMC courses (Lima, 2012). A positive impact of RVCC processes on wages was found to be limited to participants who not only obtained recognition for basic qualifications but also participated in FMC courses and to participants who obtained certifications equivalent to upper secondary education (Lima, 2012).

Today, Portuguese workers receive significantly less on-the-job training than in other countries (Figure 7, EWCS, 2015). In August 2015, Portugal introduced a training subsidy for both employees and job seekers (Cheque Formação). For employees wishing to invest in training, this subsidises up to 50 hours training with an amount of $€ 175$ and up to 150 hours of training for a maximum of $€ 500$ for each unemployed person. Training subsidies recognise the fact that the cost of training is one of the major obstacles to participation in lifelong learning (OECD, 2015a). Although available to both individuals and firms, the subsidy is being taken up mainly by firms, whose training requests account for $95 \%$ of the over $€ 3$ million requested thus far. While it is too early to evaluate the success of this measure, its potential is significant, particularly with respect to addressing firms' more immediate training needs. At the same time, the caps on the number of training hours limit its impact, and it is unlikely that this programme alone will lead to a significant upskilling or reskilling of the labour force. 
Figure 7. More effort needs to be put in upskilling the labour force

Per cent of persons who have received on-the-job training in the past year ${ }^{1}$

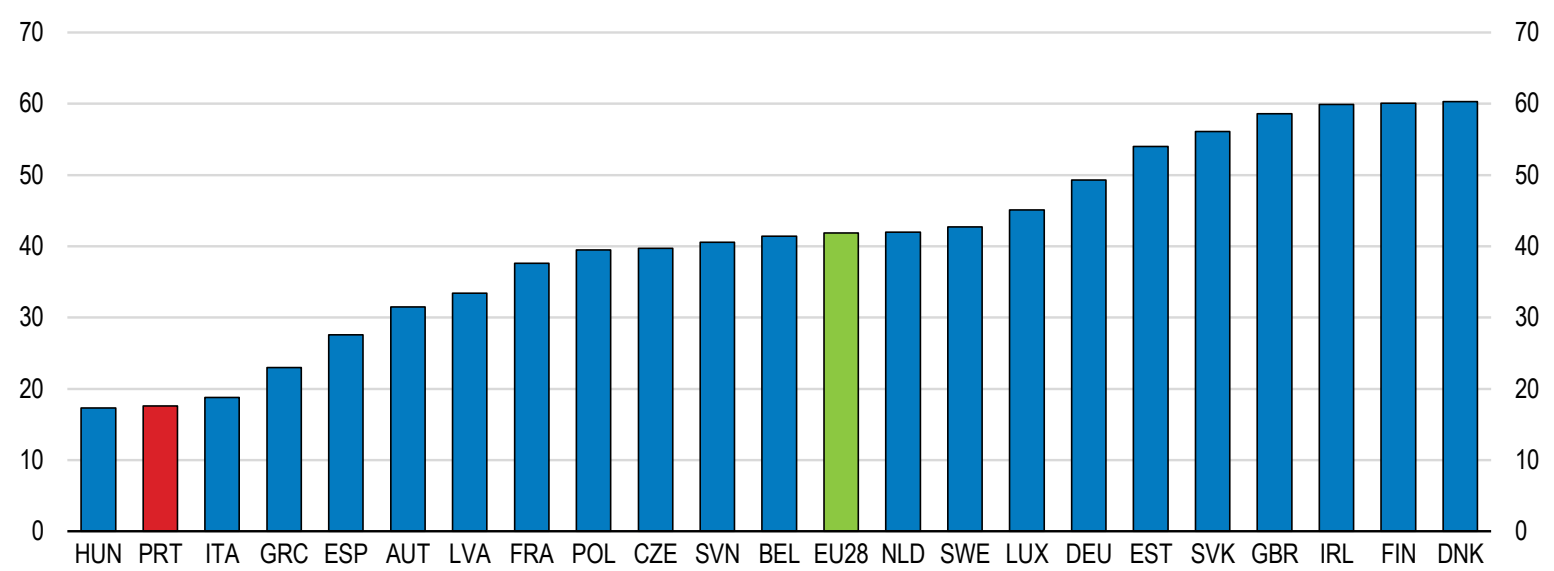

1. Share of persons responding positively to the question "Have you had on-the-job training in the past year?".

Source: Eurofound (2015), "Sixth European Working Conditions Survey: 2015”, European Foundation for the Improvement of Living and Working Conditions.

Another challenge is that it is particularly difficult to reach low-skilled individuals, which represent a large share of the labour force, with such programmes, while take-up is generally better among younger and more educated workers (OECD, 2015a). These trends are consistent with the findings of the OECD Programme for the International Assessment of Adult Competencies (PIAAC), which documents a generally weak participation of low-skilled adults in adult education and training across countries (OECD, 2013a). Across the OECD area, principal challenges for engaging low skilled workers in participating in lifelong learning activities include the cost of training, difficulties in balancing training with work and family responsibilities, and distance to home or workplace (OECD, 2015a).

Many countries have been able to attract more low-skilled workers into training by raising their awareness about existing training opportunities, but also about the opportunities to validate existing skills (OECD, 2015a). The prospects of formal recognition of existing and newly acquired skills were one factor behind the success of the New Opportunities Initiative, which instilled in participants a drive for further education and training as well as a desire to improve their work prospects (Carneiro et al, 2011).

Given the low education levels of a significant share of the population, further efforts will be required for adult training to make a real difference. A new skills strategy called "Qualifica programme" aims to increase the number of specialised centres for adult education and training (Centros Qualifica) and increase the proximity to target populations. One objective of the programme is to cut the number of adults who have not attained secondary education by half until 2020. "Qualifica programme" puts a strong emphasis on upgrading skills as it complements the process of certification with training, focusing on matching the labour market needs. The authorities need to ensure that the large scale of the programme does not weaken the quality of the training provided nor its ability to provide skills demanded by the labour market.

The successful design and development of training programmes also require systematic evaluation of the effectiveness for labour market outcomes, e.g. employability and unemployment spells, wage evolution and job quality indicators. Portugal does not have a strong tradition in policy evaluation and learning from past programmes is made difficult by the absence of ex-ante definition of monitoring and policy evaluation mechanisms. Strengthening monitoring and policy evaluation would help concentrating resources on those programmes that really make a difference for the labour market outcomes of low skilled adults. 


\section{Strengthen active labour market policies}

Activation policies, if properly designed, increase the employability of jobseekers in a cost-effective manner, making labour markets more inclusive and resilient. In Portugal, the constraints on this kind of policies have been twofold. For one, spending per unemployed relative to GDP is low in international comparison and relatively few job seekers participate in ALMP programmes (Figure 8, Panels A and B). In part, this reflects limited fiscal space. A second challenge has been to raise the effectiveness of spending on ALMPs. While fiscal space may remain limited for some time to come, past evidence suggests that improving the spending efficiency can significantly improve outcomes.

\section{Figure 8. Structure of public spending on active labour market programmes (ALMP)}

\section{A. Share of unemployed covered by ALMPs 1 Per cent, 2014}

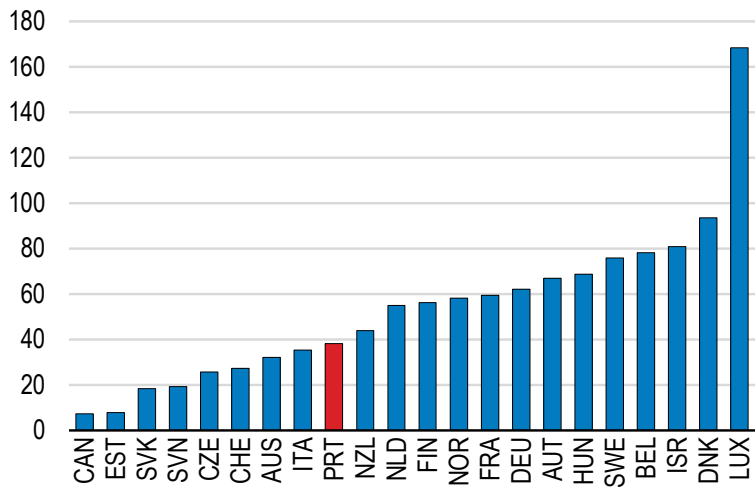

\section{Distribution of ALMP spending in Portugal} Per cent

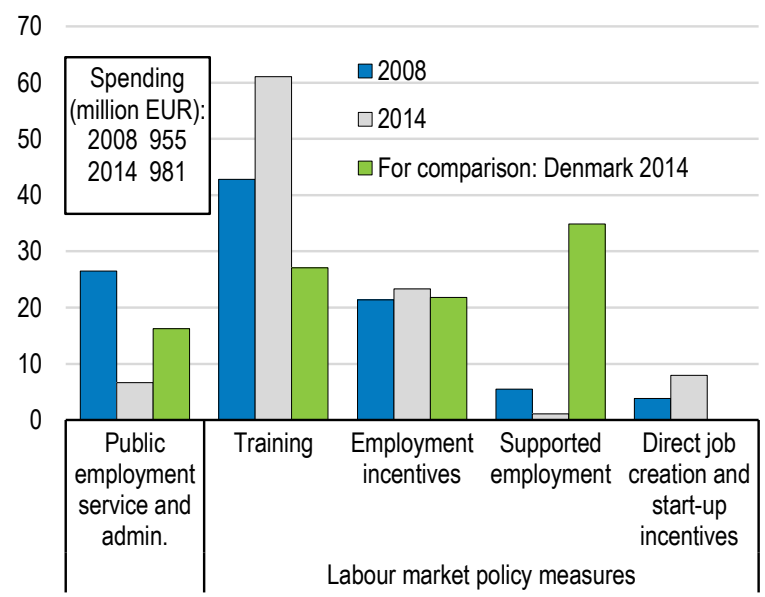

B. Spending on labour market policy measures per unemployed

As a percentage of GDP per capita, $2014^{2}$

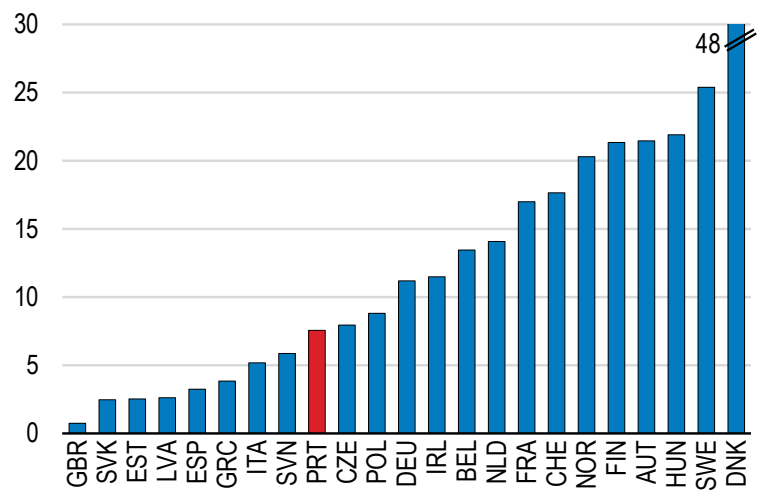

D. Public employment services caseload Job seekers per PES staff in 2013

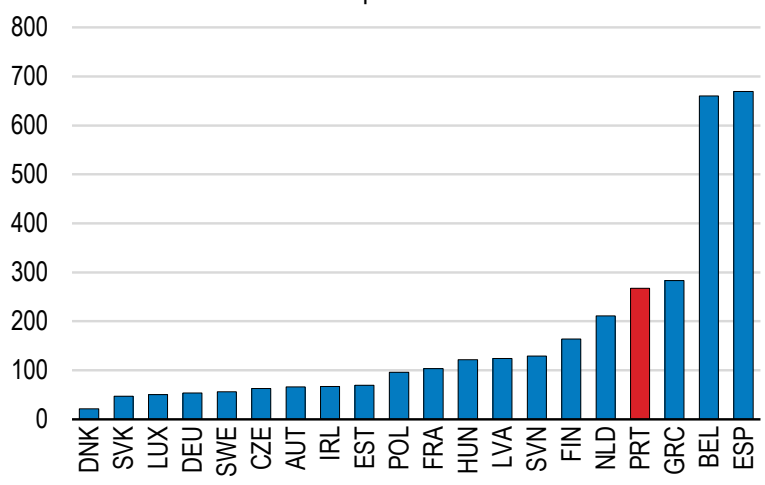

1. ALMP cover services and activities of the public employment services (PES) and labour market policy (LMP) measures that provide temporary support for groups that are disadvantaged in the labour market. The data shown should not be treated as strictly comparable across countries or through time, since data at the level of individual countries in some cases deviate from standard definitions and methods; see notes to Annex Table Q of the OECD Employment Outlook 2016 available at www.oecd.org/els/emp/employment-outlook-statistical-annex.htm.

2. 2013 for Ireland, Poland and Spain; 2011 for United Kingdom and 2010 for Greece.

Source: OECD (2016d), OECD Employment and Labour Market Statistics and OECD Economic Outlook: Statistics and Projections (databases). For Job seekers - "Persons registered with Public Employment Services - PES (source: DG EMPL)", Eurostat Database, http://ec.europa.eu/eurostat/web/products-datasets/-/Imp_rjru, accessed September 2016. For PES staff - "PES Business Models Study - Country Fiche", European Commission (June 2014). 
Portugal has stepped efforts to raise the effectiveness of activation policies. The composition of ALMP spending has shifted towards training, employment and incentives for job creation (Figure 8, Panel C). Long-term unemployed and youth not in employment, education, or training (NEETs) have been identified as target groups, both of which comprise a very high share of individuals without completed secondary education. Outreach towards the latter has improved by mobilising a large network of local partners, launching a national awareness campaign and by creating an online platform where individuals can register. The authorities have set up a Youth Guarantee scheme for those between 18 and 30 years old, which has reached more than 300,000 registered young NEET. The programme includes paid internships, which is one of the most effective ways of raising participants' employability (Martin and Grubb, 2001). Eligibility for the internship programme has later been expanded to all long-term unemployed. In spite of these efforts, the share of NEETs, like in the majority of OECD countries, is still higher than before the financial crisis (OECD, 2016a).

Lower spending on public employment services has been accompanied by efficiency improvements through an increased use of digital services, but staff in public employment services (PES) are overloaded with a high number of caseloads (Figure 8, Panel D). Moreover, the workload of career managers within the services of the PES is unevenly distributed (Table 1). Raising the number of career managers would improve the effectiveness of the personal employment plans, particularly in regions with higher unemployment but also higher demand for labour. In the absence of additional resources to hire career managers, a more balanced distribution of the caseload should be achieved.

Table 1. Distribution of caseloads in Public Employment Services ${ }^{1}$

\begin{tabular}{l|c|c}
\hline \multicolumn{1}{c|}{ Region } & $\begin{array}{c}\text { Number of career } \\
\text { managers }\end{array}$ & $\begin{array}{c}\text { Average number of caseloads } \\
\text { per career manager }\end{array}$ \\
\hline Norte & 345 & 683 \\
Centro & 180 & 437 \\
Lisboa e Vale do Tejo & 338 & 513 \\
Alentejo & 87 & 314 \\
Algarve & 53 & 510 \\
Total (on the mainland) & 1003 & 540 \\
\hline
\end{tabular}

1. April 2016.

Source: Ministry of Labour, Solidarity and Social Security (MTSSS).

Further efforts to reach out for the NEETs will require better coordination between the Public Employment Service (PES) and local partners. One way forward is to continue to expand the use of digitalisation services, including e-services aimed at employers and services aimed at matching job seekers to potential employers. This would contain costs and allow PES workers to focus more on harder-to-place job seekers or first-time job seekers. These groups typically need more face-to-face interactions and specialised counselling, as evidence from other OECD countries has suggested (OECD, 2016c, Martin, 2014). The project "One stop shop for employment" (Balcão Único do Emprego), currently under development within the SIMPLEX+ programme, may be a step forward towards greater digitalisation and coordination of public services.

Similar to adult education, Portugal's ALMP programmes could benefit from more systematic impact assessments. Multiple programs and a lack of appropriate data currently reduce the scope for systematic evaluations. Establishing a system to monitor regularly and accurately the effectiveness of the different programs would allow a better focus of future efforts on the most effective programmes. The sparse 
existing evidence points to positive results of activation measures producing effects only several years after participation (Costa Dias and Varejão, 2012).

Activation measures could be complemented with other measures to support employment, particularly for low-skilled workers. The tax burden on labour is high in Portugal and social security contributions paid by employers are flat across earnings levels (Figure 9). One option could be to lower employer social security contributions for lower incomes levels, which are likely correlated with skills. Another option could combine a more paced increase in the minimum wage with the introduction of refundable earned income tax credits, directly targeted at identified groups at greater risk of poverty.

\section{Figure 9. Employers' social security contributions are high}

As a \% of labour costs for selected earnings levels, expressed as a \% of earnings of an average worker, 2015

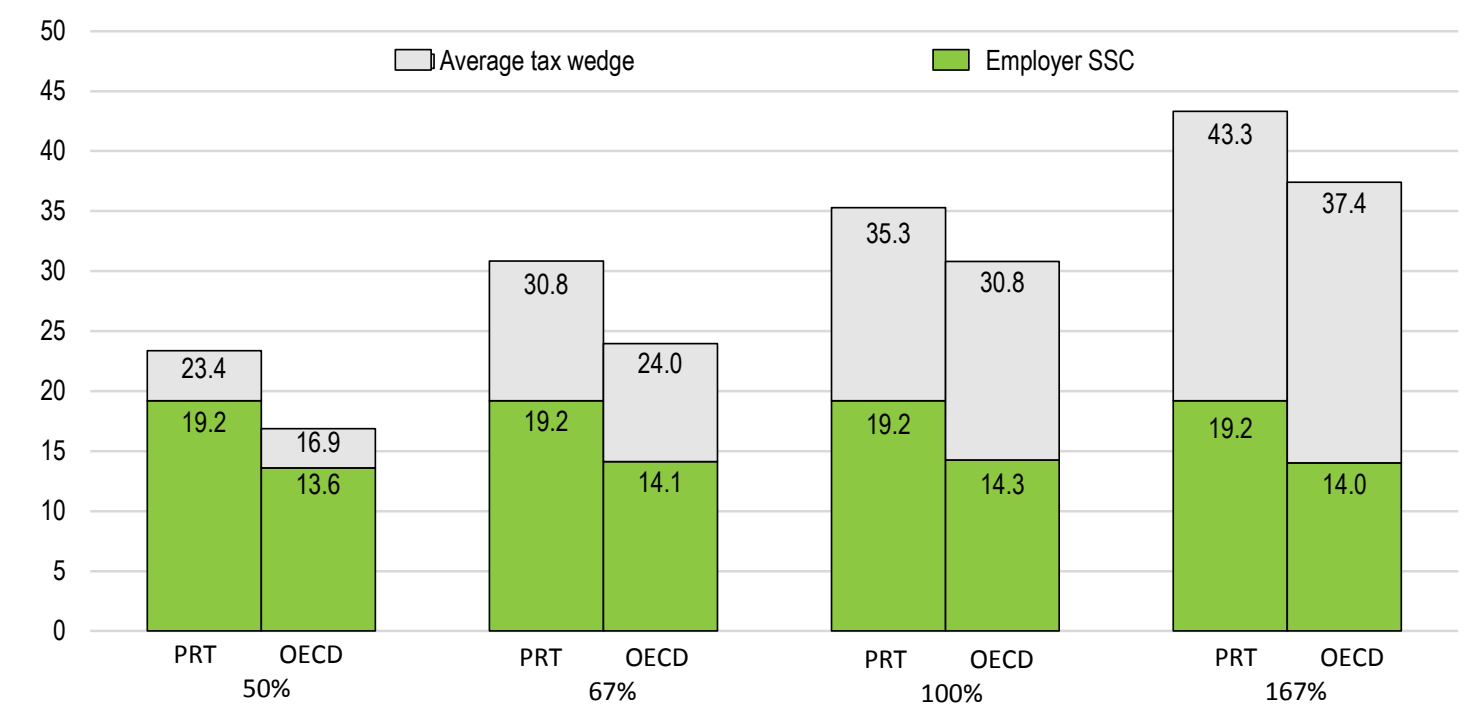

Source: OECD (2016e), “Taxing Wages: Tax wedge decomposition”, OECD Tax Statistics (database).

\section{Strengthening primary and general secondary education}

\section{Learning outcomes are improving}

Besides adult education and measures to promote labour market insertion, the education system is the obvious tool for improving the skills of Portuguese citizens. The effectiveness of Portugal's education system has improved substantially over time. Performance in successive rounds of the PISA tests shows an improvement over time in students' learning outcomes (Figure 10, Panel A). In the 2015 PISA evaluation, performance was above the OECD average in science and reading and around the OECD average in mathematics. Disaggregated PISA results suggest noticeable improvements across different types of schools and programmes, including both public and private schools (Ferro et al, 2015a). PISA results for Portugal are consistent with enhanced performance in other standardised international tests such as the TIMSS (Trends in International Mathematics and Science Study, 2015) and PIRLS (International Results in Reading, 2012). 
Figure 10. Selected indicators of education performance

Programme for International Student Assessment (PISA)
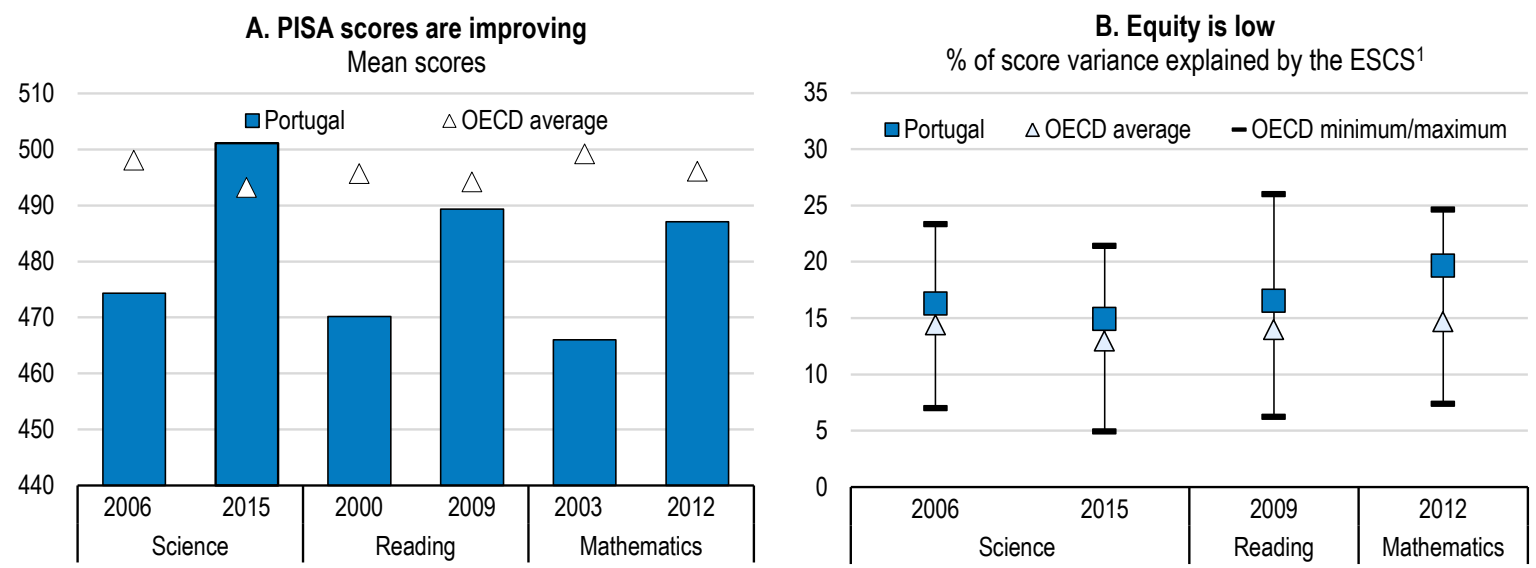

C. The share of top performers is at the OECD average $^{2}$

D. The share of low performers has declined ${ }^{3}$

Per cent of students
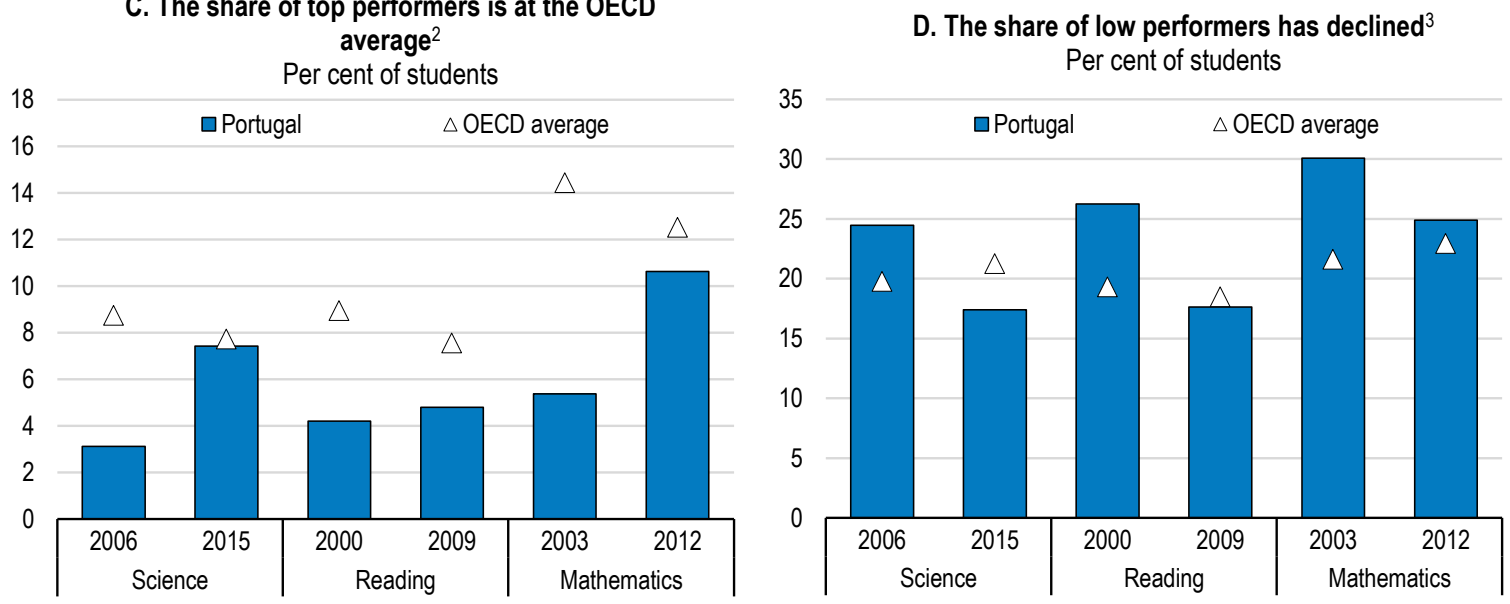

1. ESCS is the PISA index of economic, social and cultural status.

2. Proficiency level 5 or above on a scale of 1 to 6 .

3. Proficiency below level 2 on a scale of 1 to 6 .

Source: OECD (2016f), PISA 2015 Results: Excellence and Equity in Education (Vol. I); OECD (2014b), PISA 2012 Results: What Students Know and Can Do (Vol. I); (OECD 2013b) PISA 2012 Results: Excellence Through Equity (Vol. II); OECD (2010a), PISA 2009 Results: Overcoming Social Background (Vol. II) and OECD (2008), PISA 2006, Vol. 2: Data.

Portugal's improvements over time are visible both at the top and the bottom of the score distribution. Between 2006 and 2015, the share of top performers in science increased (i.e. those students that reached Level 5 or 6 in PISA tests) while the share of low performers decreased (i.e., those students performing below Level 2) (Figure 10, Panels C and D). However, the share of top performers has declined between 2012 and 2015 and almost one in five students is below proficiency Level 2, which is considered by the OECD as the baseline level of mathematical proficiency that is required to participate fully in modern society (OECD, 2014c).

\section{The education system needs to do more to reach to disadvantaged children}

Education outcomes seem more adversely affected by the student socio-economic background than elsewhere (OECD, 2016f). The share of variation in students' scores that can be explained by their socio-economic status is around 15\%, which is higher than the average of $13 \%$ across the OECD 
(Figure 10, Panel B). Moreover, the strength of the relationship between performance in PISA tests and the socio-economic background has increased, suggesting a deterioration in equity (Figure 21, OECD, 2016f). Improvements in average scores do not need to come at the cost of deteriorating equity, as the example of Italy illustrates. In 2003, Italy had a similar performance level as Portugal and its average PISA scores have seen similar improvements between 2003 and 2012, but equity has improved in Italy during this period, while it has deteriorated in Portugal (OECD, 2015a). While Italy managed to keep raising both performance and equity in PISA tests in the 2015 PISA tests, Portugal's significant improvement in performance was not accompanied by a similar improvement in equity. PISA results also illustrate that high average performance and equity are not mutually exclusive: several OECD countries, including Australia, Canada, Estonia, Finland, Japan, Korea, the Netherlands, and the United Kingdom combine an average performance above the OECD average with a weak relationship between socio-economic status and student performance (OECD, 2016f).

\section{Early school leaving prevents strong skill acquisition}

Inequities in the education system are related to Portugal's high school drop-out rate. Around $14 \%$ of youth between 18 and 24 years old have left school without completing secondary education (Figure 11). Early school leaving, defined as the proportion of youth between 18 and 24 years of age who has attained at most lower secondary education, has been successfully brought down from 63\% in 1991 to about $14 \%$ in 2015 but attaining the 2020 target of $10 \%$ will be very hard to achieve (CNE, 2015). The high share of students leaving the education system too early with low skills does not allow society to capitalise on resources invested in education. Compulsory education has been progressively extended and since 2009 covers 12 years, from age 6 to 18 , but this has done little to keep students in school.

\section{Figure 11. Early school leaving rate and targets}

Percentage of the population aged 18 to 24 having attained at most lower secondary education and not being involved in further education or training ${ }^{1}$

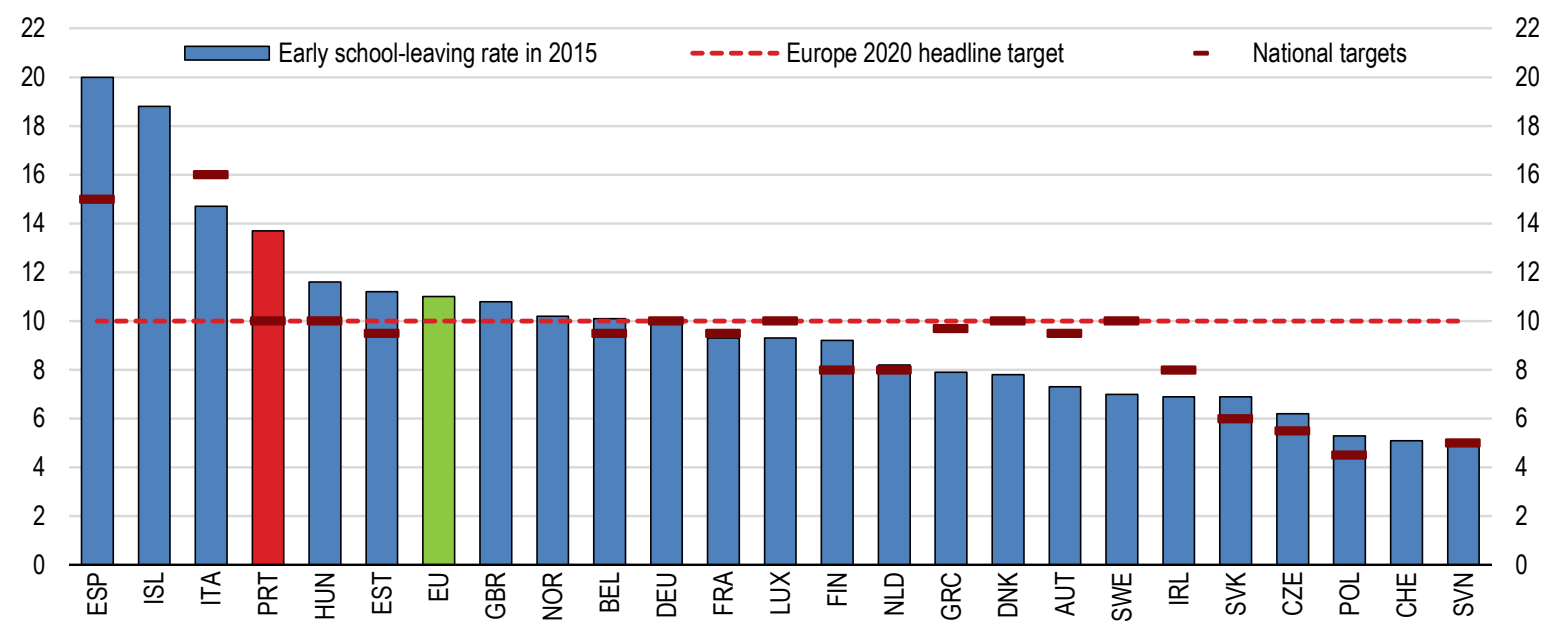

1. The early school leaving rate for Spain covers "school drop outs". The United Kingdom has no national target.

Source: Eurostat (2016b), "Youth education and training", Eurostat Database and European Commission (2014), "Overview of Europe 2020 Targets", http://ec.europa.eu/europe2020/targets/national-targets/index_en.htm.

Evidence suggests that one strong predictor of dropping out of school is grade repetition (Roderick, M, 1994; Ferrão, Beltrão and Santos, 2002, 2007; Ferrão and Fernandes, 2003; Lyche 2010; Manacorda, 2012). The Portuguese education system uses grade repetition more frequently than other countries. In 2012, 34\% of students in Portugal reported having repeated at least once in primary or secondary education. This proportion is the fourth highest among OECD countries and well above the OECD average 
of $12 \%$ (Figure 12). More than $10 \%$ of Portuguese students repeat already at grade two. While there has been a decreasing trend in the use of grade repetition between 1996 and 2009, it is not clear from more recent data whether this decline is put on a firm steady path (Ferrão, 2015).

Figure 12. Grade repetition is too commonly used and entails high costs

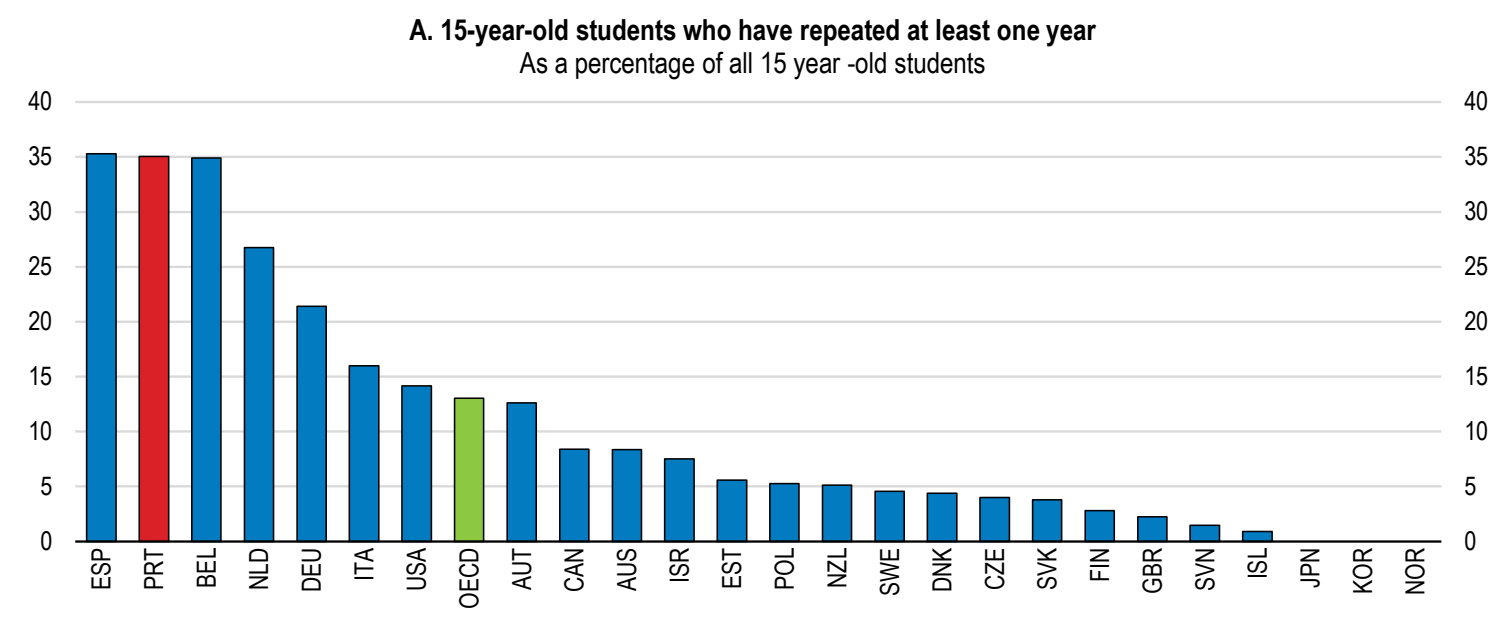

B. Total annual costs of repetition

Relative to total expenditure on primary and secondary education, per cent ${ }^{1}$

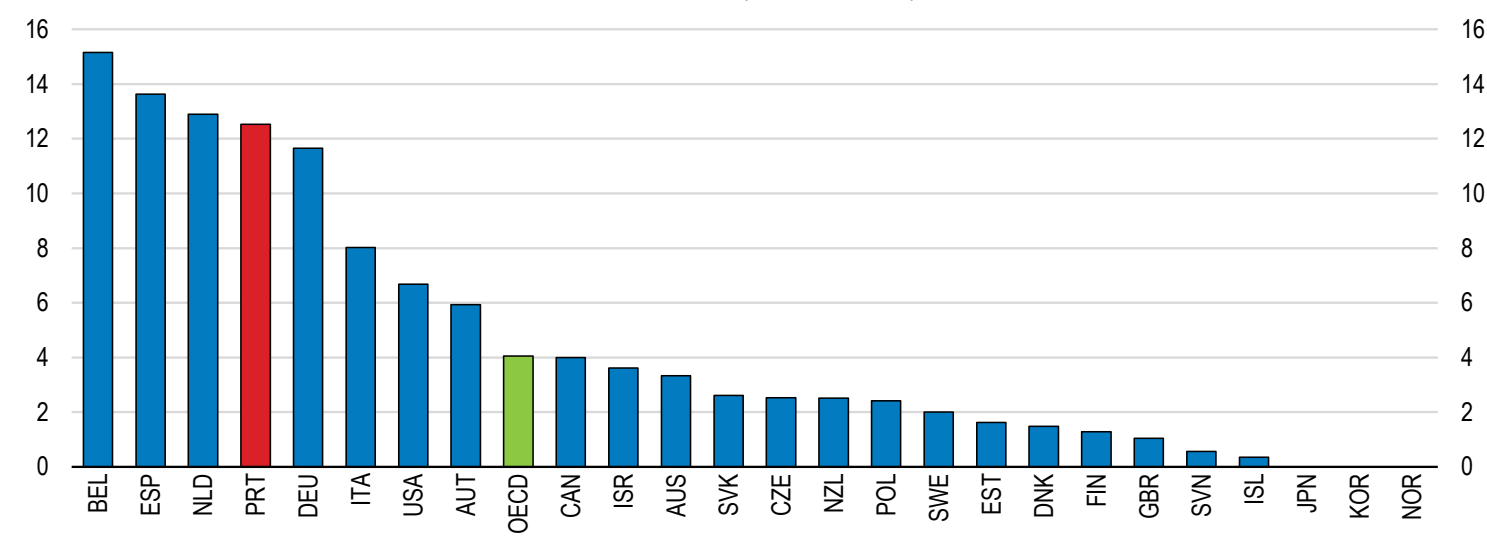

1. Relative to total expenditure on primary and secondary education. Cost estimations refer to 2007 or the latest available year and represent the total costs of grade repetition for one age cohort, including the opportunity cost of one year of the student's time.

Source: OECD (2012), Equity and Quality in Education: Supporting Disadvantaged Students and Schools.

Grade repetition is generally considered an ineffective way of supporting underperforming students and it often has negative effects on students' learning outcomes over the long term (Baenen 1988; Pagani et al, 2001; Roderick and Nagaoka, 2005). In Portugal, early grade repetition (ISCED 1 level) is a strong predictor of grade repetition later in the education path (Reis and Pereira, 2015), which is consistent with an absence of beneficial effects on learning outcomes. As disadvantaged students are more likely to repeat grades, it reinforces inequalities (OECD 2014d; Ferrão, 2015). While across the OECD 20\% of socioeconomically disadvantaged students reported having repeated a grade at least once, this figure jumps to more than 50\% in Portugal (OECD, 2015a). Students with immigration backgrounds have particularly high repetition rates. Grade repetition is not only ineffective, it is also costly, comprising both the extra expenditure incurred in the repeated year and the opportunity costs of one year of the student's time. 
Finding alternatives to grade repetition is likely to lead to better outcomes. More could be done to identify students at risk early on and individualised support should be granted to them. The government's project of offering mentoring to students that have repeated at least twice is very welcome but there is a risk that this support comes too late, and late interventions are less likely to succeed (Nusche et al, 2015). The government intends to attribute mentoring roles to teachers, but this should be combined with specific training for teachers on how to perform this role. Another policy option is to step up the programme Mediators for School Success, established by an association called "Entrepreneurs for Social Inclusion" (Associação de Empresários pela Inclusão Social, EPIS), which has been active since 2006. The programme managed to reach to 1700 students. Its trained mediators have a strong track record of raising students' educational performance (OECD, 2015a).

Students' evaluation relies strongly on assessing student performance against pre-defined standards and benchmarks (summative assessment). More emphasis should be given to providing regular feedback to students and to developing opportunities for strengthening teacher-student discussions about the student's learning progress (Santiago et al, 2012). These elements of formative assessment are key to provide students falling behind with individualised teaching strategies and should integrate the overall strategy to identify learning difficulties early on. The current government is determined in striking a better balance between formative and summative assessment by incentivising the diversification of assessment practices and abolishing national standards and exams in primary education in the academic year 2015/6 (Implementing Order 1F/2016).

The most effective way to ensure equitable access to learning opportunities comes at a very early age. International experience shows that high quality early-childhood education and care (ECEC) reduces the impact of socio-economic background and improves skill accumulation, employment prospects and earnings later in life (Cunha et al., 2005; Almond and Currie, 2011; Doyle et al., 2013). In Portugal, the coverage of pre-primary education has increased rapidly and in 2013 reached a participation rate of $78 \%$, $90 \%$ and $98 \%$ for children aged 3, 4 and 5 years-old, respectively, all of which are above the corresponding OECD averages (OECD, 2015b). In 2016 the universalisation or pre-schooling was achieved for children aged 4 to 6 years old and the government plans to reach the same target for 3 year olds in 2019. However, the average number of pupils to teaching staff in early-childhood education (17) is the third highest among European OECD countries (13, on average) and well above that of countries such as Australia, Finland, Denmark, New Zealand and Sweden, all of with a ratio of 10 of below. Also, participation rates declined in the aftermath of the economic crisis as unemployment soared and there are concerns of whether ECEC education is accessible to low-income families. PISA data shows that low-performing students participated much less in early-childhood education than in other OECD countries (OECD, 2016a). As a consequence, children from disadvantaged socio-economic backgrounds should become the primary target group for continued efforts to expand early childhood education. Besides expanding the system, a stronger focus on quality is also crucial, particularly as - in stark contrast to international evidence - there is so far no firm evidence of lower grade repetition among students who were enrolled in pre-primary education (Reis and Pereira, 2015, OECD 2012).

\section{The structure of spending will require further adjustments}

Despite high education expenditures relative to GDP, Portugal's annual expenditure per student is low in comparison with other OECD economies, but there is no direct link between education expenditure and outcomes (Figure 13). Indeed, some countries achieve similar or higher PISA results with similar or lower spending. This may point to scope for improving the efficiency of education expenditure, including through further changes in the structure of spending. Such changes have already been successful in the past. Smaller student cohorts resulting from demographic changes have led to a re-organisation of the public school network that allowed significant improvements in spending efficiency. Salary cuts and the 
freezing of career progression for civil servants, including those working in public education, as well as reductions in the number of staff have also reduced the public education expenditures.

Figure 13. Allocation of resources in education ${ }^{1}$

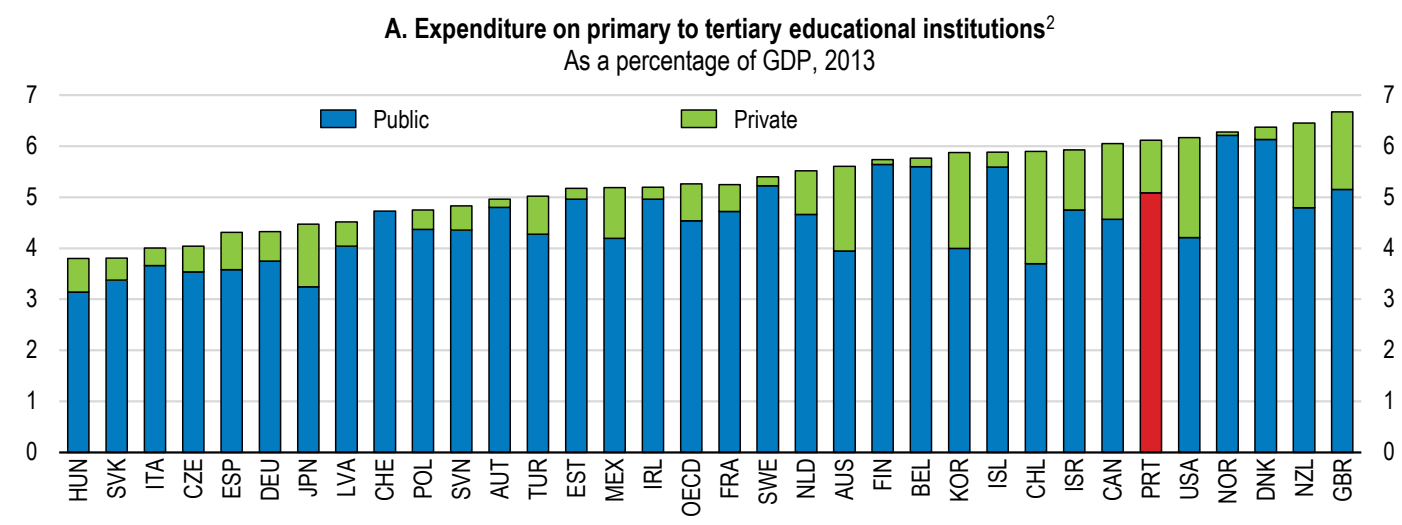

B. Annual expenditure on primary to tertiary educational institutions per student ${ }^{3}$ In thousand USD equivalent (calculated using purchasing power parities [PPP]), 2013

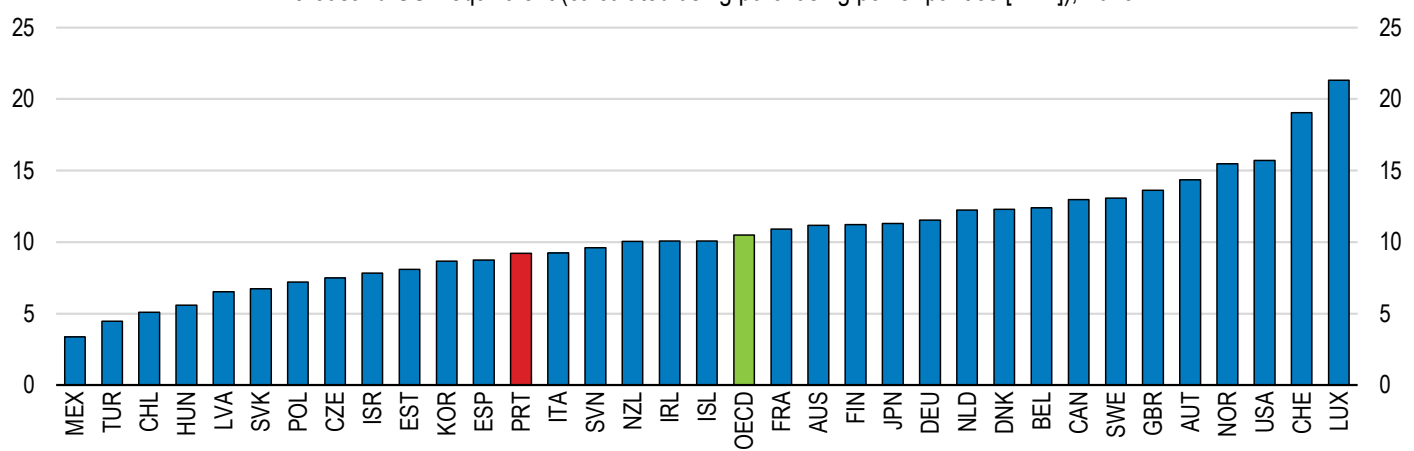

C. There is no direct link between spending and relative PISA scores ${ }^{4}$

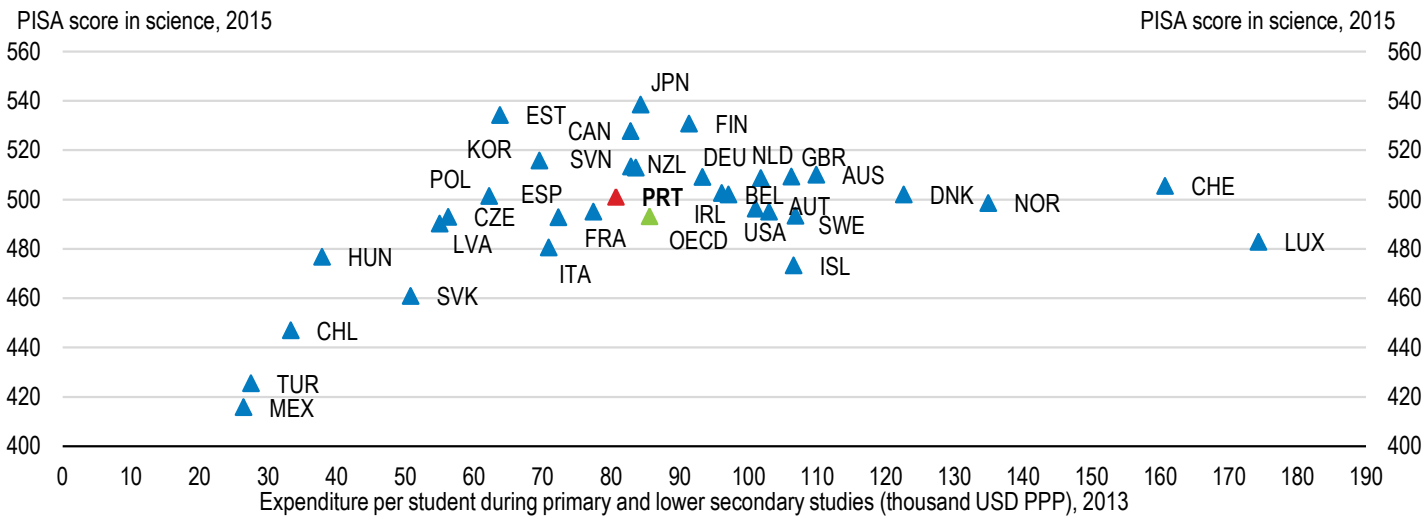

1. Expenditure in 2012 for Canada and 2014 for Chile. The OECD aggregate is an unweighted average of data shown (including Latvia).

2. Public expenditure only for Switzerland.

3. Public institutions only for Ireland and Switzerland. Public institutions only for tertiary level for Canada, Luxembourg and the Slovak Republic.

4. Cumulative expenditure per student over the theoretical duration of primary and lower secondary studies relative to Programme for International Student Assessment (PISA) scores in mathematics. Public institutions only for expenditure for Ireland, Italy, Poland and Switzerland.

Source: OECD (2016a), Education at a Glance 2016: OECD Indicators and OECD (2016f), PISA 2015 Results: Excellence and Equity in Education (Volume I). 
Portugal spends nearly $80 \%$ of education resources on staff compensation, which is more than other OECD countries, reflecting the rather low student-teacher ratio, particularly in secondary education (Figure 14). Although the evidence on the optimal class size is not conclusive, smaller class sizes in Portugal have not been successful in reducing grade repetition, although they should allow devoting more attention towards low achievers without penalising other students. Looking ahead, maintaining a small student-to-teacher ratio could be one possible strategy, given the authorities' commitment to reduce repetition rates. However, given that the returns on investment in human capital are greatest in the early years of schooling, focusing such a strategy on primary and pre-primary education rather than secondary education may be the most promising way forward (Odden, 1999; Carneiro and Heckman, 2003; Heckman and La Fontaine, 2007; Nusche et al, 2015). Another option is to rethink the use of teachers' time to offer more individualised support to students at risk of falling behind, including through mentoring schemes.

Figure 14. The student-teacher ratio is low

Number of students per teaching staff in educational institutions, $2014^{1}$

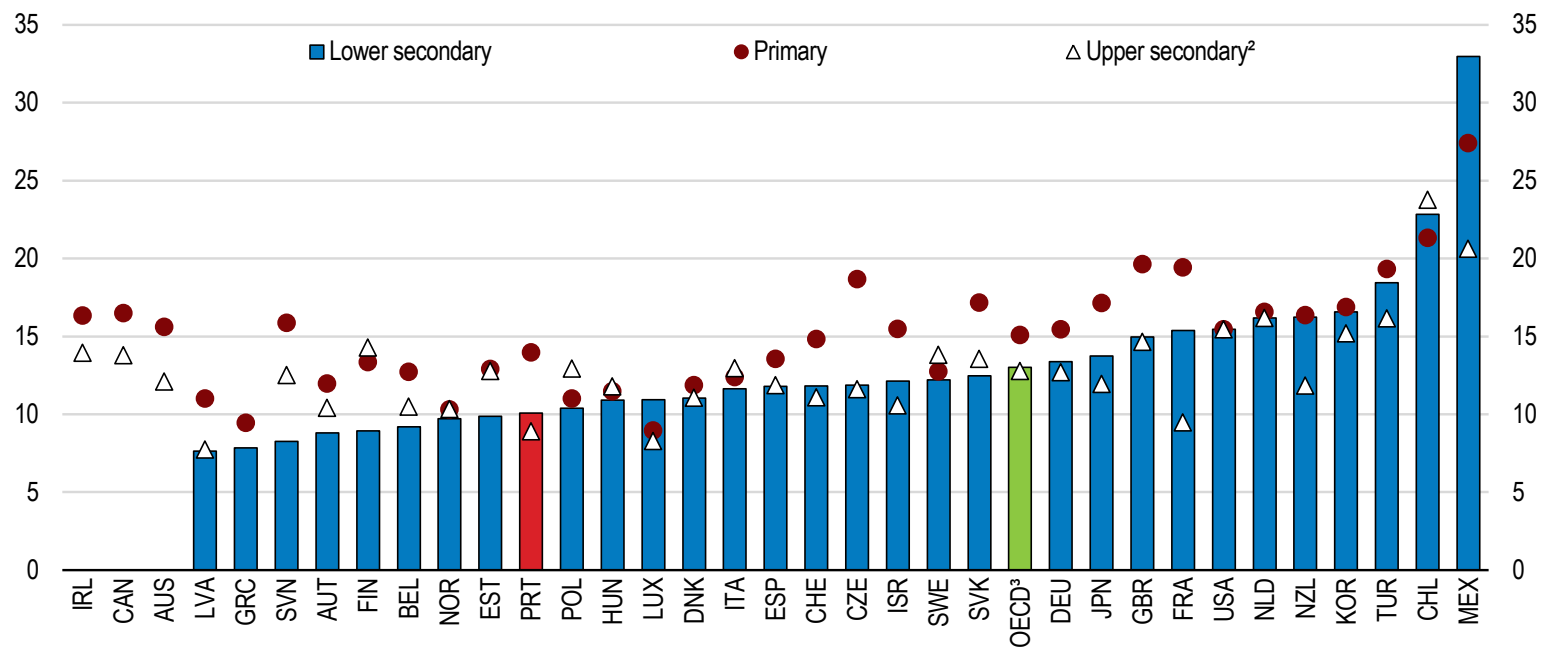

1. Public institutions only for Ireland, Israel (upper secondary), Netherlands and Switzerland. 2012 for Canada where primary includes pre-primary and lower secondary.

2. General upper secondary programmes. Includes lower secondary for Australia and Ireland. Refer to all upper secondary programmes for Canada, Israel, Japan, Greece, Norway, Portugal, Sweden and the United States.

3. Unweighted average of data shown including Latvia.

Source: OECD (2016a), Education at a Glance 2016: OECD Indicators.

\section{Teachers' skills could be improved further}

The quality of teachers and their teaching are the most important factors in student outcomes that can be influenced by policies and good teachers can make a real difference in schools with a disproportionate share of students from low socio-economic backgrounds (OECD, 2005; OECD, 2012). In the past when the education system was expanding rapidly, the quality of teachers was a challenge, but recent initiatives have strengthened teacher qualifications. These initiatives include more stringent admission conditions, reinforced scientific curricula in teacher education programmes and a new training framework for teachers that links continuing professional development to career progression (OECD, 2006; OECD, 2014e). The legally required qualifications to access the teaching profession consist of a 5-year training programme and a probationary period of one year.

Still, there is evidence that the exposure of Portuguese teachers to international best practices could be improved, in particular with regard to collaboration among teachers, which is rare in Portugal (Figure 15, 
Panel A, OECD, 2016f). New teachers could also receive stronger support from their schools as Portugal has the lowest rate of access to formal induction, both for all new teachers to the school and for teachers new to teaching (Figure 15, Panel B; OECD 2016f). While a large majority of teachers engage in professional development (85\%), only a small share of teachers participate in training sessions involving teaching to students with special needs, even though this is the area where most teachers report greater need for professional development (OECD, 2014e). Another weakness of the education system is that teachers receive little evaluation and feedback on their work. Improving peer-learning by moving away from a "closed doors" culture and building professional networks to share teaching experiences could provide the basis for a stronger contribution of teachers to raising skill levels in Portugal. The National Programme for School Success, in order to provide additional resources (more human resources, as well as teachers' and principals' on-job training) to local projects developed by schools, in collaboration with municipalities.

\section{Figure 15. Teachers' skills need to be improved}

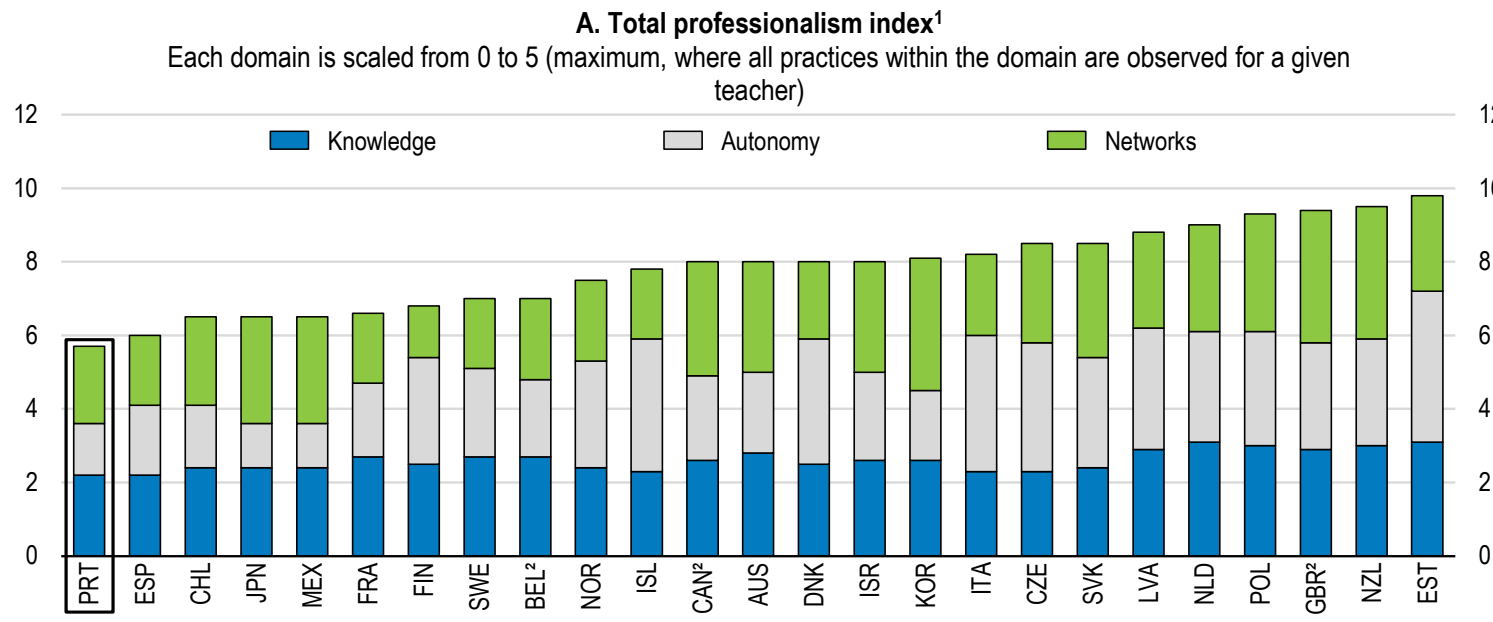

B. Teachers' access to formal induction is low

$\%$ of lower secondary education teachers whose school principal reports the existence of formal inductions, 2013

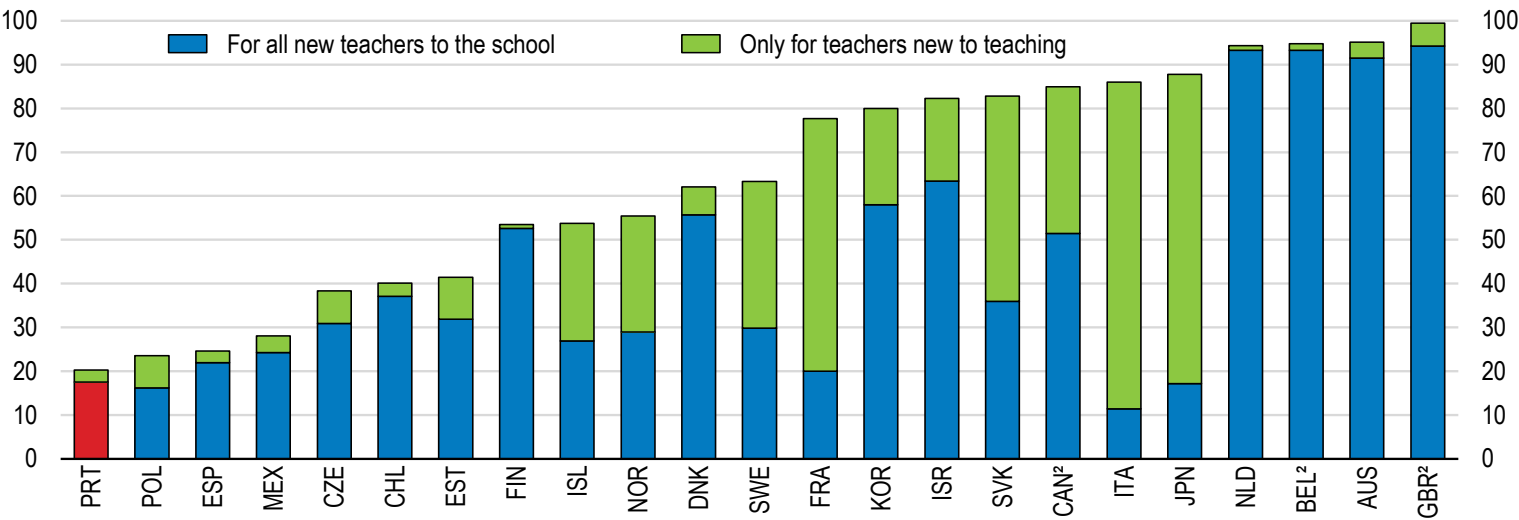

1. Knowledge: presence of teaching credentials and support for continued professional development. Autonomy: amount of decision-making power teachers have over aspects of their teaching, as reported by principals. Peer networks: role that teachers play in regulating their own peer networks of practice.

2. Sub-national entities: Flanders for Belgium, Alberta for Canada and England for the United Kingdom.

Source: OECD (2016g), Supporting Teacher Professionalism: Insights from TALIS 2013 and OECD (2014f), Talis 2013 Results: An International Perspective on Teaching and Learning. 


\section{Improving governance}

The education system remains fairly centralised, providing schools with little autonomy (OECD, 2006; Santiago et al, 2012). Funding is per class and schools have no say on the number of classes or their size (CNE, 2015). Giving schools more autonomy in adapting size classes to students' needs would enable them to concentrate more resources where they are most needed. Teacher allocation across schools is also centralised and the governing principle is a teachers' ranking system based on the classification of entry into the profession and years of experience, with no role for performance evaluation. This system does not reflect the special needs of schools in remote areas or with a high share of students from disadvantaged backgrounds, which are often staffed with early-career teachers on temporary contracts and have a high turnover of their teaching staff. Giving schools the autonomy to decide whether to retain non-permanent teachers could lead to some improvements, but in the longer run, there may be scope for providing stronger incentives for more experienced teachers and school principals to work in disadvantaged schools.

Progressive autonomy for schools should be accompanied by a well-designed evaluation and assessment framework, as recommended in the 2006 OECD Economic Survey (OECD, 2006) and in a 2012 OECD review of evaluation practices in the Portuguese education system (Santiago et al, 2012). Evaluations of students and schools should be based on the learning progress made by their students, as opposed to their level of performance, which is strongly influenced by socio-economic factors. Students' learning progress should be measured by a combination of standardised test results and teachers' qualitative evaluations of students' progress (Santiago et al, 2012).

More systematic evaluations should also be applied to the many programmes implemented by schools to reduce grade repetition and early school dropout (OECD, 2015a). This would allow identifying successful strategies to address these issues across schools. Schools play a critical role in student performance and students of similar socio-economic backgrounds can have very distinct performance paths according to the school they attend (DGEEC, 2016). At present, the education system is not making best use of the learning opportunities that its own experiences provide.

\section{Ensuring equal access to tertiary education}

After years of stellar progress in expanding tertiary education, completion rates have fallen by almost 20 percentage points since 2008 and tertiary enrolment among those younger than 23 has decreased sharply (EC, 2016, CNE, 2015). A nationwide study is currently being undertaken to understand the reasons behind these developments in tertiary education and preliminary results point to the role of insufficient academic preparation as well as financial difficulties (Ferreira and Fernandes, 2015; Baptista, 2015). A specific programme call "Retomar" has been launched in order to provide financial support to those who have abandoned their studies and wish to re-enrol in tertiary education.

The strong marks of students' socio-economic backgrounds are also visible in access to tertiary education, which is particularly unequal in Portugal. Youths from families with high levels of education have a much higher probability of reaching a higher level of education than others (Figure 16). Financing tertiary education may be one of the issues. All tertiary education students in Portugal pay tuition fees, ranging from EUR 656 to 1063 per annum for undergraduate degrees. Fees are fixed within the same range for those advanced degrees that are legal requirements for the practice of a certain professions, while they are not regulated for all other advanced degrees. 
Figure 16. Relationship between students' participation in higher education and socio-economic status Odds ratio of being a student in higher education by parents' educational level, $2009^{1}$

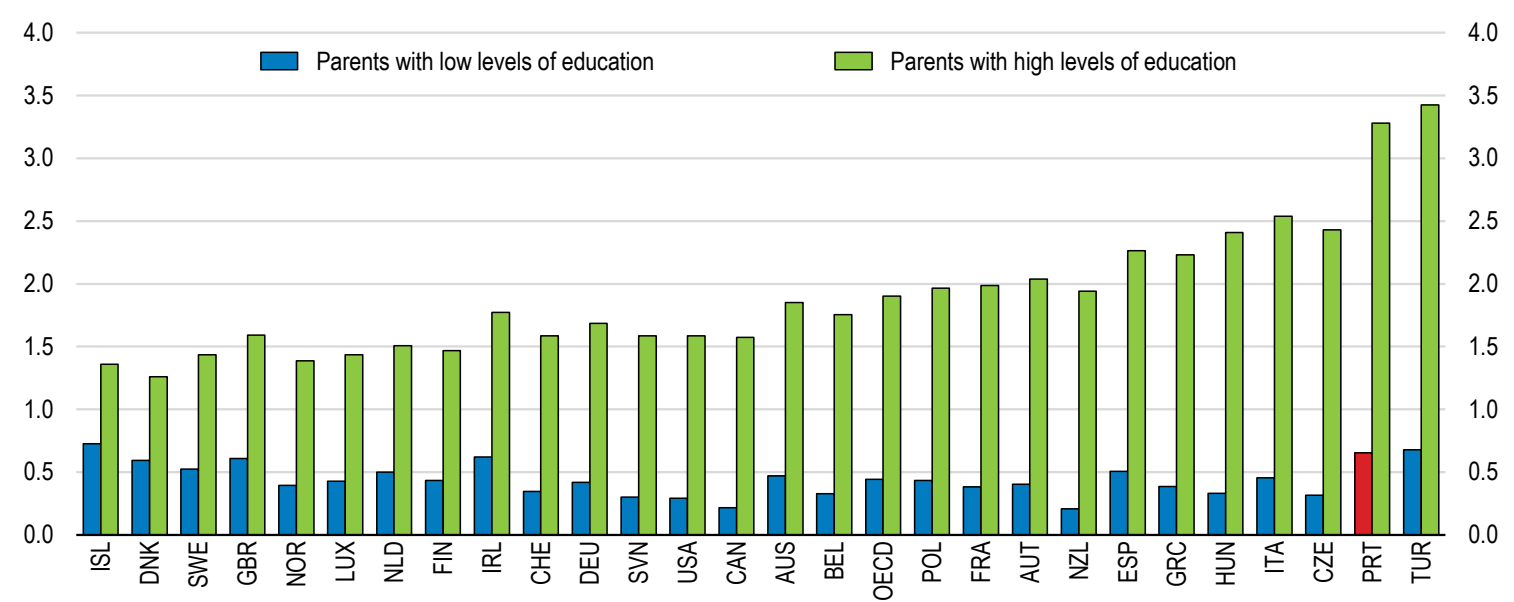

1. This figure shows the odds of someone from a low (or high) educational background attending higher education. The odds ratio is calculated by comparing the proportion of parents with low (or high) levels of education in the total parent population to the proportion of students in higher education whose parents have low (or high) levels of education. If young people from a low (or high) educational background were as likely to attend higher education as those from more (or less) educated families it would result an odds ratio equal to 1 . Countries are ranked in increasing order of difference between the odds ratios of being a student in higher education with low and high educational backgrounds.

Source: Table A6.1 in OECD (2012), Education at a Glance 2012: OECD Indicators.

Public support for tertiary students, consisting of both merit-based and needs-based grants, reaches almost half of tertiary students, but may not be generous enough for students from disadvantaged backgrounds. Need-based grants awarded on the basis of family incomes vary between EUR 1063 and EUR 5 675. These are topped up by merit-based grants of EUR 2525 for students who obtained high grades in the previous academic year. Additional grants of EUR 1500 were awarded for the first time in 2014/15 to a maximum of 1000 students who moved to study in regions where tertiary education institutions currently have excess capacity.

Even from a purely fiscal perspective, the current grant system is a good investment, provided that it really induces more youths to take up tertiary studies. OECD calculations suggest that the returns in terms of extra tax revenue collected are more than the twice the costs incurred by the government in financing tertiary education (Figure 17). These high returns result from a combination of comparatively low spending on tertiary education and student support on the one hand and comparatively high labour market premiums for college education on the other (OECD, 2016h). This strengthens the case for giving more generous student support to tertiary students from disadvantaged backgrounds, which would likely prove a powerful tool to reduce inequalities. 
Figure 17. Average returns to costs ratio of government investment in tertiary education ${ }^{1}$ 2011

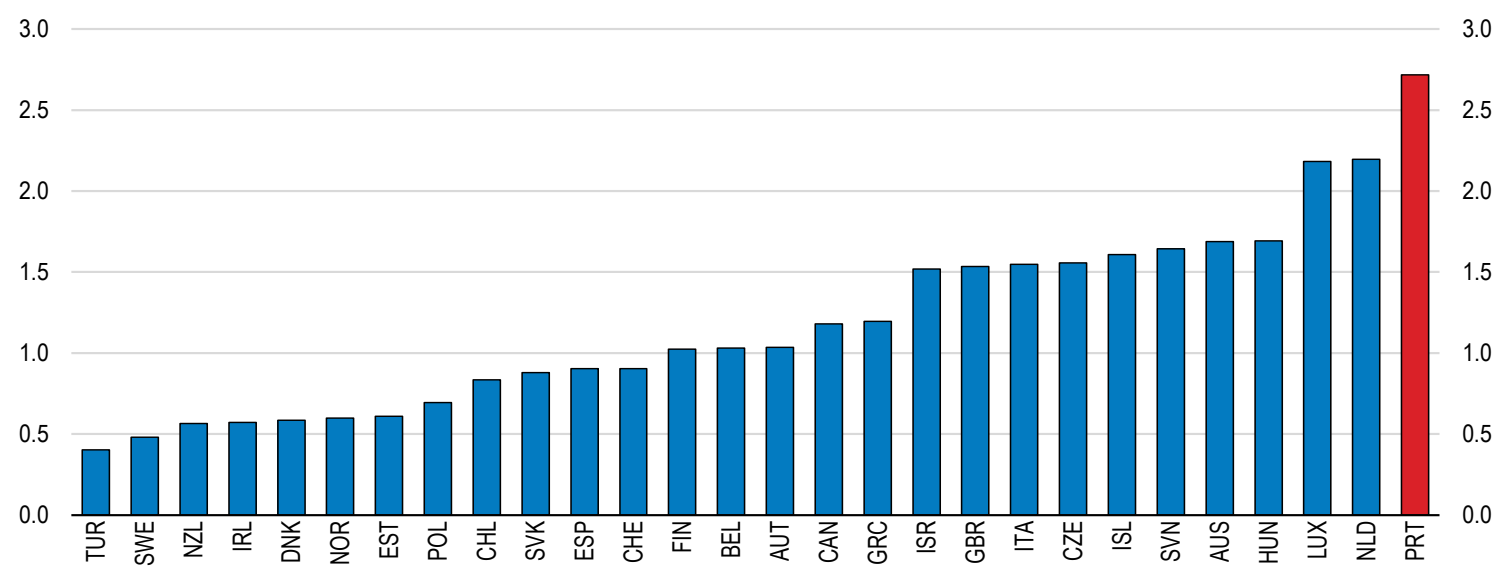

1. The average returns to costs ratio (ARCR) measures the ratio of government returns to education (extra tax revenue) to the cost of education (lost tax revenue, direct costs, scholarship or grant income given to a student and the value of skills tax expenditures). Data are for a 17 year-old single taxpayer with no children, who undertakes a four-year course of non-job-related education, earning $25 \%$ of the average wage during schooling.

Source: OECD (2017), "Taxation and skills”, OECD Tax Policy Studies, No. 24.

\section{Matching qualifications to the labour market needs}

Effective and well-informed career guidance at the end of lower secondary education plays an important role in achieving a good match between students' preferences and the labour market needs (OECD, 2014g). A number of study areas that lead into career paths with low unemployment are facing low demand from students (Figure 18). A lack of information about labour market prospects may be one reason behind this and this could be addressed by better career guidance. Recently established "Qualifica Centres" provide guidance and counselling to adults and NEETs on education and training opportunities and were meant to increase the collaboration between employers and educational institutions at the local level. The extent to which they are delivering the intended results has not yet been evaluated. 
Figure 18. Enrolment is low in areas of reduced unemployment

Percentage share by field of study, average 2010-15

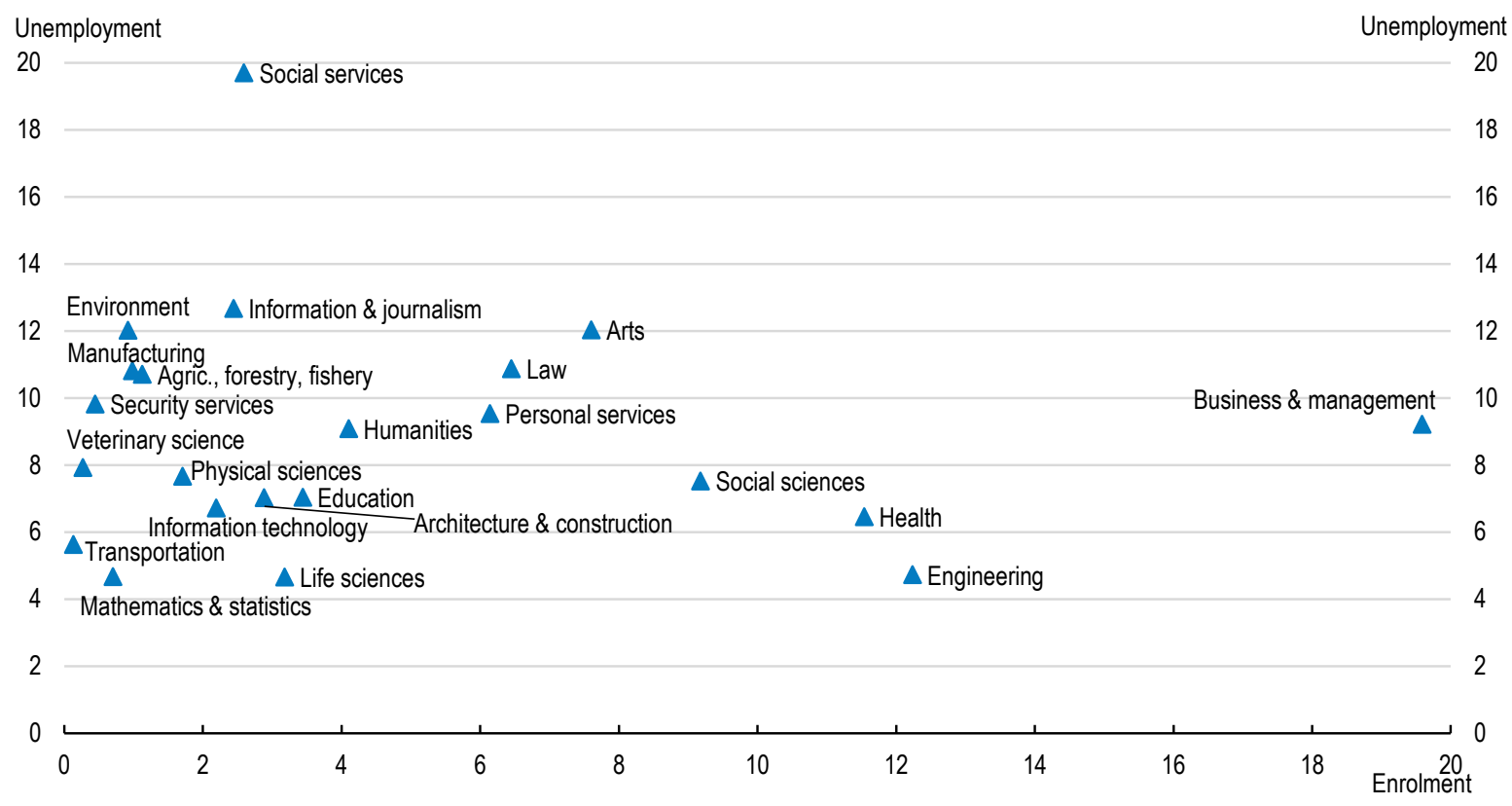

Source: Calculations based on data from Direção-Geral de Estatísticas da Educação e Ciência (DGEEC).

The supply of tertiary education could also benefit from a stronger focus on labour market needs. Currently, there are vacancies in courses with unemployment rates above $20 \%$, compared to the average unemployment rate of $8 \%$ among tertiary graduates. There are currently about 711 different college degrees, 506 of which being offered in a single institution (CNE, 2015). Streamlining the supply of courses would make it easier for students to take informed decisions that correspond to labour market needs.

\section{Strengthening vocational education and training (VET)}

Vocationally-oriented upper secondary education often leads to better employment prospects than academic-oriented courses for those students that do not pursue tertiary education studies (CEDEFOP, 2013). Portugal's education system has traditionally had a strong bias towards general and academicallyoriented programmes, but the development of VET has caught up very rapidly with the OECD average in the past decade, raising doubts about the quality of the offer. In 2014, 46\% of students in upper-secondary education were enrolled in VET courses, the same as the OECD average (Figure 19). 
Figure 19. Upper-secondary vocational education and training enrolment rates

Percentage of students, $2014^{1}$

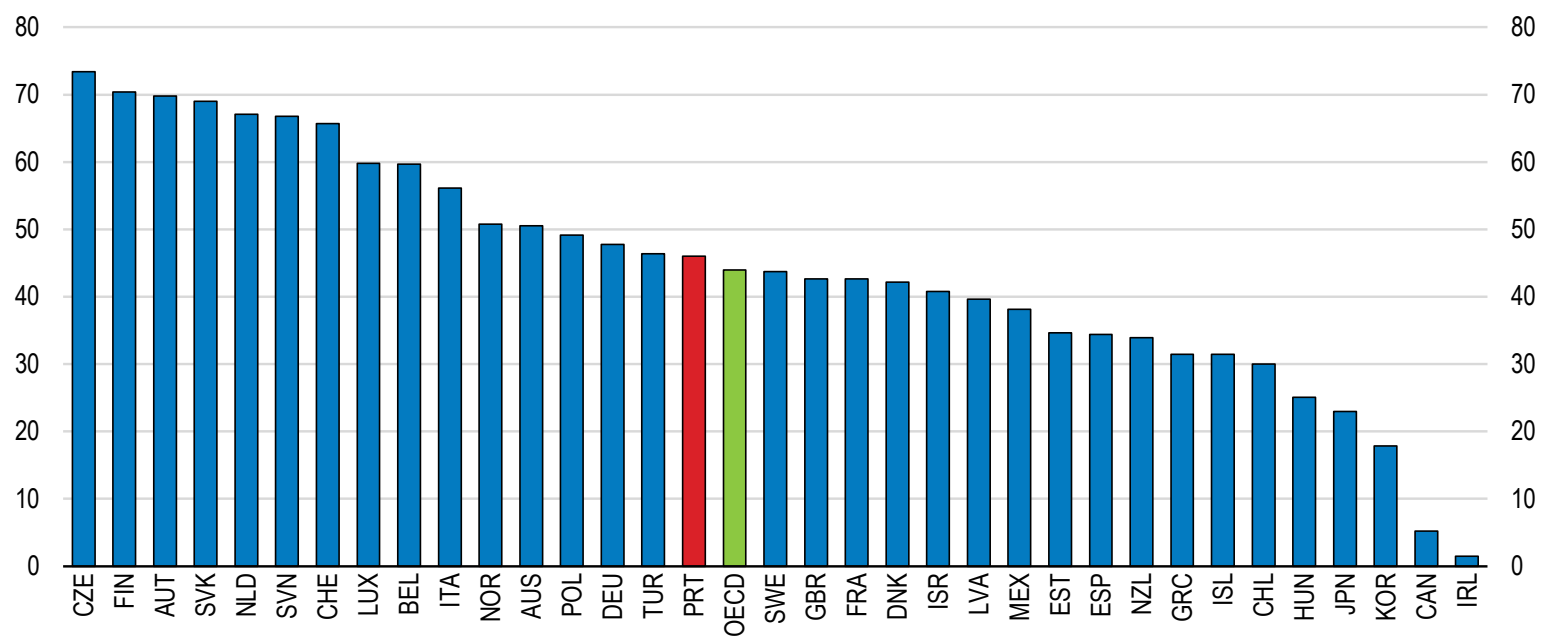

1. 2013 for Canada, Iceland, Ireland and Netherlands; no data available for the United States. The OECD aggregate is an unweighted average including Latvia.

Source: OECD (2016a), Education at a Glance 2016: OECD Indicators and OECD (2015b), Education at a Glance 2015: OECD Indicators.

The offer of VET courses has been expanded to encompass a wide range of higher skilled occupations such as renewable energies, electronics and automation, ICT among others (OECD, 2015a). Services, sciences, engineering and manufacturing represent $60 \%$ of VET graduates, above the OECD and the EU22 average (OECD, 2016a). The authorities are keen to keep developing the VET system, raise its attractiveness and ensure that it is linked to the labour market needs. These efforts could benefit from better coordination and a merger of two almost parallel systems. This issue was acknowledged by the authorities during the last decade, leading to many governmental actions, including the creation of a national agency to supervise all adult education and VET programmes (Agência Nacional para a Qualificação e o Ensino Profissional), the National System of Qualifications and the Anticipation System of Qualification Needs. These efforts have been reinforced in 2016, by establishing a national system of credits in all VET courses (aligned with European Credit on VET framework), the Qualifica Passport and the reactivation of the National Council for VET (Conselho Nacional para a Formação Profissional). Nonetheless, both the governance of the VET system and VET provision is still divided across two Ministries, which creates a risk of overlaps and inefficiencies in the use of resources and reduces the effectiveness of quality control. Rationalising the offer and building on strengths of each VET provider will be a more cost effective way of expanding VET while guaranteeing the quality of training.

The Ministry of Education has the main responsibility for vocational training courses designed for youth at secondary education level. These VET programmes have academic and technical components and often include some kind of practical training, organised within the schools, with little or no work-based learning. At present, it is hard to evaluate to what extent the VET offer under the responsibility of the Ministry of Education is meeting labour market needs, particularly as there is no systematic evaluation of participants' labour market performance (Pedroso, 2011). Post-secondary VET is under the tutelage of the Ministry of Science, Technology and Higher Education. Recent policy initiatives aimed at strengthening post-secondary VET by establishing two-year technical courses with a strong workplace learning content (Cursos Técnicos Superiores Profissionais, TeSP) in 2014/15. Enrolment and private sector participation in these courses have exceeded expectations. Currently, more than 500 courses have been approved, although 
not all of them are operational yet. More than 18000 internship placements have been announced, involving almost 6000 private employers.

The Ministry of Labour also coordinates and delivers VET courses through the Institute for Employment and Vocational Training (Instituto de Emprego e Formação Profissional, IEFP). These are either taught by employment and training centres (Centros de Emprego e Formação Profissional, CEFP), by 23 sector-oriented training centres operated in collaboration with social partners (Centros de Formação Profissional de Gestão Participada), and by around 170 external accredited entities. In these centres, labour market outcomes are tracked over time, although not always in a consistent way. The majority of these centres survey the employment rate of graduates 6 or 12 months after completion through questionnaires. A more systematic and detailed evaluation of participants' labour market outcomes would allow aligning course offer and the quality of training to the labour market needs.

Besides the Ministry and Education and IEFP, VET is also provided by private training providers, including employers and trade unions. Although these entities need to be certified if seeking public funding, there are concerns about the quality of training being provided (OECD, 2015b). The capacity to monitor the quality of training and the labour market outcomes of VET needs to be strengthened. This includes developing indicators by VET pathway, course enrolment and VET provider. These indicators should be compiled regularly and be used in policy evaluation with a view of streamlining the VET offer, training quality and to align student enrolment with the labour market needs through reinforced career guidance, starting at the end of lower secondary education.

In addition to existing VET courses, the Ministry of Education is currently planning to establish a network of Vocational Schools of Business Reference (Escolas Profissionais de Referência Empresarial) with a focus on economic priority sectors and a strong technical component. While close links to the private sector are generally a desirable feature of any VET, in this case there is a strong risk of duplicating the already existing structure, as the CEFP managed by the Ministry of Labour have this sector expertise and enjoy a close relationship with businesses.

Merging the fragmented VET system will bring clear benefits in terms of better coordination and efficiency and should go along with a thorough evaluation of all existing VET education programmes. A consolidated VET system should try to preserve the best features of the current parallel systems. Providing solid general skills in VET programmes is important as a solid basis for further learning and allows making effective use of the existing bridges between all VET pathways and other parts of the education system.

In addition to general skills, a strong component of work-based learning, generally referred to as a dual system, should become a crucial feature of all VET programmes. At present, IEFP courses are more dual in nature and ensure a stronger link to the private sector than the VET courses run by the Ministry of Education. International evidence suggests that dual training, in school and at the work place, enhances the employment prospects of participants substantially (OECD, 2015a). Austria, Germany and Switzerland have successfully implemented dual VET systems (Box 2).

Dual systems require tight collaboration between businesses and schools. In some of the economically less dynamic regions, finding businesses that can provide work-based training is likely to be challenging and alternative solutions may have to be explored. One option would be to build on the wide network of well-equipped IEFP vocational training centres. Another is to channel these students into well-established private VET organisers. As some students may have to move to receive training, providing financial assistance for this should also be considered. 


\section{Box 2. Dual VET Systems}

Countries have different approaches to the preparation of young people for the labour market ranging from the dual system, with apprenticeship training built into formal schooling, to the US model, where young people may gain work experience informally outside the school system in part-time jobs and through job rotation. In countries with a strong dual system, vocational training is widely respected and integrates work-based and school-based learning to prepare apprentices for a successful transition to full-time employment. A major strength of the dual system is the high degree of engagement and ownership on the part of employers and other social partners. Strong dual systems also ensure that the short-term needs of employers do not distort broader educational and economic goals.

\section{Workplace training}

- In Germany, a training directive specifies the professional competences in the occupation that should be acquired by students during in-company training. These requirements guarantee uniform national standards irrespective of current enterprise needs. The training enterprise draws up an in-company training plan for trainees. This plan must correspond to the training directive broadly but may deviate from it if particular features of company practice require this (Hippach-Scheider, Krausse, Woll, 2007).

- In Switzerland, ordinances (Verordnung über die Berufsbildung) specify how instruction time should be divided between schools and companies. They also require the establishment of a training plan for each occupational field that defines the curriculum and organisation of in-company training. Training plans are set up by organisations including social partners and accepted by the Federal Office for Professional Education and Technology. Cantons license companies to take apprentices and periodically evaluate provided training against national standards. Cantonal inspectors enter companies to ensure that training received by students is up to the standards. If a problem is detected, the cantonal staff intervene through coaching to assist the company. The companies see that this is to their advantage, in that if they train the apprentice better, the apprentices do better work for them. Self-evaluation of companies is also encouraged. A list of 28 criteria of good training, prepared in co-operation with social partners, guides companies in their work with students (for more information see www.qualicarte.ch/).

- In Denmark, trade committees in which employees and employers are equally represented approve and inspect enterprises that want to take in trainees on the basis of defined criteria. To be approved, an enterprise must have a certain level of technology, and a variety of tasks to be performed to ensure the trainee carries out a full range of occupation related activities (Danish Ministry of Education, 2005).

- In Austria, the apprenticeship offices (Lehrlingsstellen) that are attached to the chambers of commerce and industry (employer organisations), examine if enterprises are able to offer apprenticeship training with regard to corporate and legal conditions and human resources requirements. They examine and record apprenticeship contracts, and are competent in principle for all issues that are in the interest of the apprentice and training providers. The apprenticeship offices are supported in their work by the apprenticeship and youth welfare units of the chambers of labour (employees' organisations). Employee bodies are mandated to defend the interests of apprentices, their main task is to monitor the training provided by employers and to appoint delegates to bodies responsible for apprenticeship. In the exercise of their activities apprenticeship offices are subject to State instruction (ILO, Vocational Education and Training in Austria, www.ilo.org/public//english/employment/skills/hrdr/publ/009.htm).

Source: Kuczera, M. (2010), A Learning for Jobs Review of the Czech Republic: 2010, OECD Reviews of Vocational Education and Training, OECD Publishing, Paris.

Countries with dual VET systems typically formalise training contracts between the apprentices and the employer rather than schools or training centres (Austria, Denmark, Germany, Netherlands, Norway and Switzerland). Trainees should receive compensation for their work to encourage learning and incentivise employers to provide good quality training, but at about $60 \%$ of median wages, Portugal's minimum wage may turn out to be an obstacle in this respect. Possible remedies for this could include introducing a tax-free minimum wage for apprenticeships or financial incentives for firms that provide training. 
Finally, continuous evaluation and assessment, based on systematically collected, detailed information on the labour market performance of graduates from each VET course, should provide the basis for learning from past experiences and for constant improvements of the existing VET offer.

\section{Maximising incentives for individuals to invest in skills}

One of the main motivations for individuals to acquire skills, besides personal enrichment, is the prospect of accessing more stable and better paid employment, including opportunities for further career development in the future. While tertiary education graduates currently earn between $60 \%$ and $110 \%$ more than those with secondary education (Figure 20), the incentives for acquiring skills could be much stronger. A series of structural bottlenecks are currently limiting the rewards for better skills in Portugal. These include labour markets, whose dual nature implies that even those with stronger skills face severe challenges in securing stable and attractive jobs. In addition, the demand for high-skilled labour and hence the incentives for upskilling could be significantly stronger if Portuguese firms were managed more professionally. Low management skills are currently holding back the professionalisation of Portuguese firms, which limits not only the growth potential of firms themselves, but also the employment opportunities for the high-skilled, particularly in cases where managers with low skills fail to appreciate the potential contributions of high-skilled professionals. Finally, scarce links between research and business tend to limit the employment opportunities for the very high skilled to academic institutions, which deprives them of significant earnings opportunities in the private sector, including through the pursuit of dual careers.

\section{Figure 20. Returns to skills by occupational group}

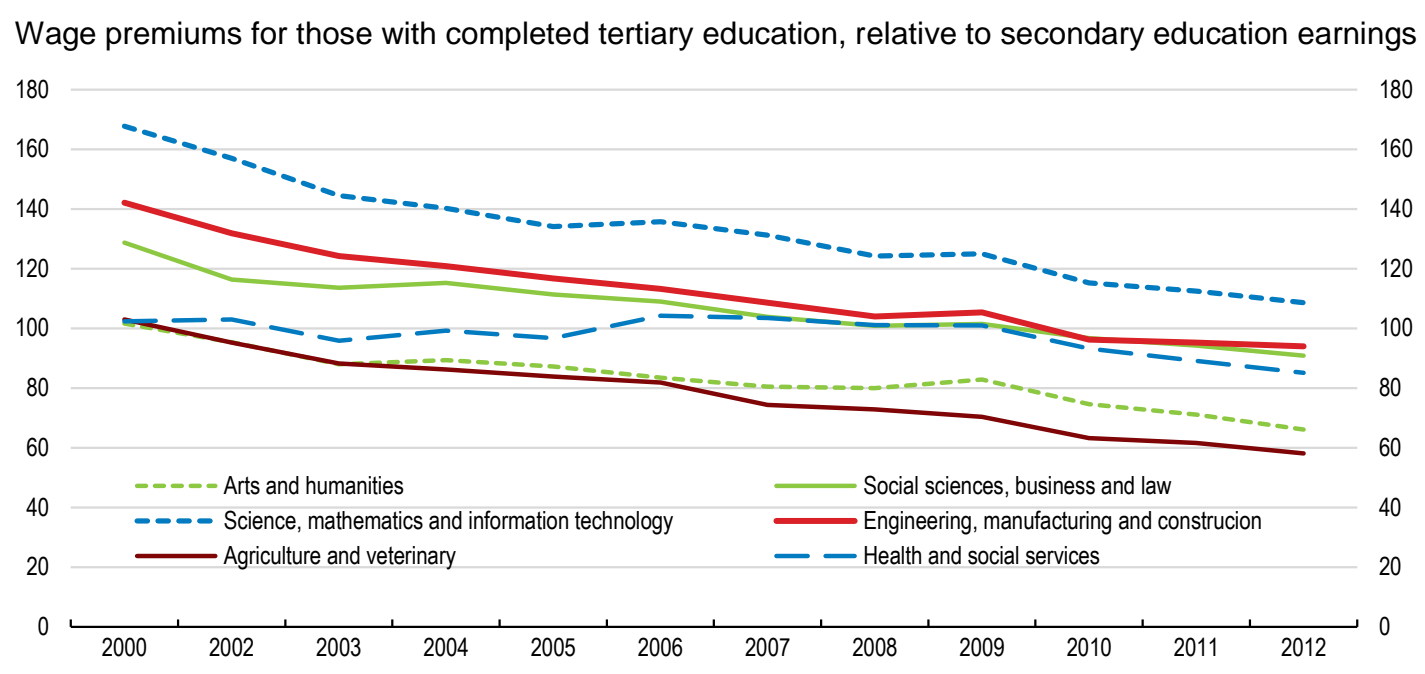

Source: A. Almeida et al. (2016), "Economic and non-economic returns to higher education in Portugal", Research Report commissioned by Fundação Francisco Manuel dos Santos and the universities of Aveiro, Minho/NIPE and Porto/CIPES.

\section{Labour market segmentation reduces incentives for individuals to invest in skills}

The dual nature of Portugal's labour market, with a heavily protected segment of workers on permanent contracts coexisting with a sizeable share of workers on temporary contracts, leads to strong job turnover among those on temporary contracts. High job turnover reduces the incentives for employers and employees to invest in their relationship and thus hampers productivity growth (Boeri, 2011; OECD, 2010b). Firms are more likely to provide training to regular workers rather than to temporary workers (Booth et al., 2002; OECD, 2002, Dolado et al, 2002; Bentolila et al., 2008). For workers in the temporary segment, frequent job changes come at significant costs, both with respect to earnings and the rapid obsolescence of their job-specific skills and experience. Higher education attainment does not improve the 
odds of entering the permanent segment of the labour market, which significantly reduces the incentives for individuals, particularly young people, to acquire skills.

Strong employment protection in the permanent segment is probably one of the factors behind the size of the temporary segment. Portugal still has one of the largest regulatory gap between temporary and permanent contracts. Since 2012, significant labour market reforms have been undertaken to reduce this segmentation, including significant reductions in severance pay for new hires. As the accumulated rights of existing workers have been largely preserved, the effects of this reform on labour market duality will only be felt in the future and recent data suggest only a small reduction in the share of temporary contracts. More time is required to evaluate the effects of recent labour market reforms (OECD, 2016e).

One way to reduce employers' reluctance to hire on permanent contracts would be to clarify the circumstances under which a dismissal can be categorised as a dismissal for economic reasons. Although this may require a constitutional change, other countries such as Italy and Spain have recently enacted such reforms. Dismissals for economic reasons are one category of dismissals with a "just cause", while those "without a just cause" are still prohibited and have not been affected by recent reforms at all. Another way forward would be to introduce a new open ended labour contract with initially low levels of employment protection that increase gradually with tenure (Carneiro et al, 2014; Boeri et al, 2013; Bentolila et al, 2012; Centeno and Novo, 2012).

\section{Low managerial skills are holding back the potential contributions of high-skilled professionals}

Many of the tasks that highly skilled professionals can perform are only used in firms with state-ofthe-art management practices, which are generally associated with improved performance in terms of profitability, growth and survival (Bloom et al., 2012; 2016; Adalet McGowan et al, 2015). At the aggregate level, differences in management practices account for a sizeable share of cross-country productivity differentials (Andrews and Westmore, 2014).

Managerial skills are quite poor in Portugal, particularly among domestically-owned firms (Figure 21). Estimates suggest that they account for around $30 \%$ of the productivity gap of Portugal relative to the US (Bloom et al, 2016). But low managerial skills do not only hold back the growth of firms, they also have direct implications for high-skilled labour demand.

The overwhelming majority of firms in Portugal are small and managed by individuals with low educational attainment, which are often the owners and founders of the firm (Table 2). The use of professional management is underdeveloped in these firms (Figure 22). One of the reasons for this could be the failure of low-skilled company owners to appreciate the potential value that a highly trained professional, e.g. a university-trained marketing manager, could bring to their company. Alternatively, owners may simply be suspicious of hiring people with significantly higher skills than their own. 
Figure 21. Management skills are low

Management score, scale 1-5 (from worst to best practice) ${ }^{1}$

A. Overall management score density

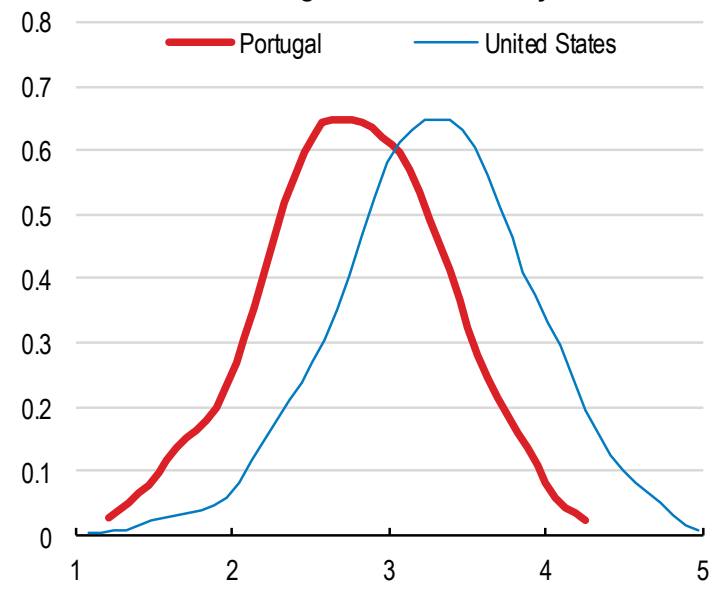

B. Domestic firms versus foreign multinationals²

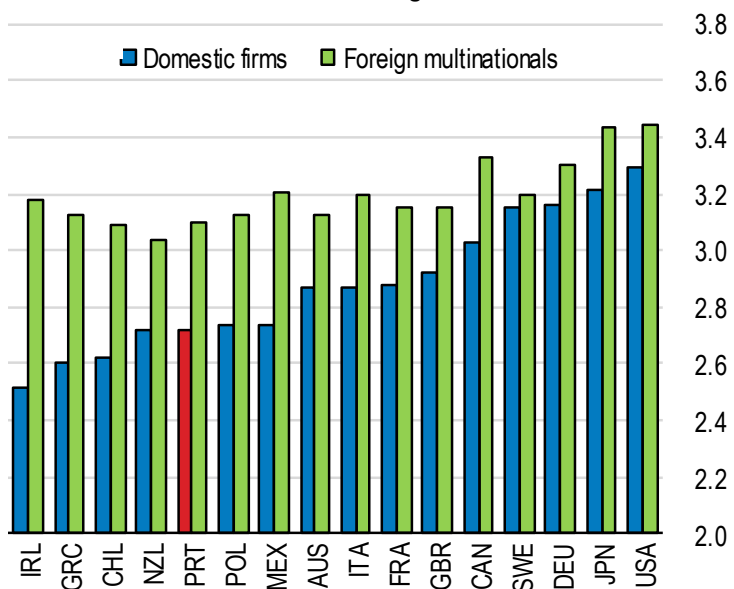

1. Average score across 18 key management practices evaluating responses to questions on monitoring, targets and incentives. The methodology defines a badly managed organisation as one that fails to track performance, has no effective targets, and bases promotions on tenure with no system to address persistent employee underperformance. In contrast, a well-managed organisation is defined as one that continuously monitors and tries to improve its processes, sets comprehensive and stretching targets, and promotes high-performing employees and fixes (by training or exit) underperforming employees.

2. Multinationals in manufacturing and retail sectors.

Source: N. Bloom et al. (2012), "Management practices across firms and countries", NBER Working Paper Series, No. 17850, National Bureau of Economic Research and World Management Survey, www.worldmanagementsurvey.org.

The overwhelming majority of firms in Portugal are small and managed by individuals with low educational attainment, which are often the owners and founders of the firm (Table 2). The use of professional management is underdeveloped in these firms (Figure 22). One of the reasons for this could be the failure of low-skilled company owners to appreciate the potential value that a highly trained professional, e.g. a university-trained marketing manager, could bring to their company. Alternatively, owners may simply be suspicious of hiring people with significantly higher skills than their own.

Table 2. The qualification of managers is low

\begin{tabular}{lcc}
\hline \multicolumn{1}{c}{ Educational attainment } & ISCED level $^{1}$ & $\begin{array}{c}\text { Per cent of } \\
\text { managers }\end{array}$ \\
\hline Lower secondary & 2 & 53.9 \\
Upper secondary & 3 & 24.9 \\
Post-secondary non-tertiary & 4 & 1.0 \\
Short-cycle tertiary & 5 & 2.4 \\
Bachelor or equivalent degree & 6 & 16.1 \\
Master & 7 & 1.2 \\
Doctorate (PhD) & 8 & 0.4 \\
\hline
\end{tabular}

1. ISCED: international standard classification of education.

Source: A. Almeida et al. (2016), "Economic and non-economic returns to higher education in Portugal", Research Report commissioned by Fundação Francisco Manuel dos Santos and the universities of Aveiro, Minho/NIPE and Porto/CIPES. 
Figure 22. Professional management is scarcely used

Global competitiveness index ranging from 0 (non-professional) to 7 (professional management), 2014-15

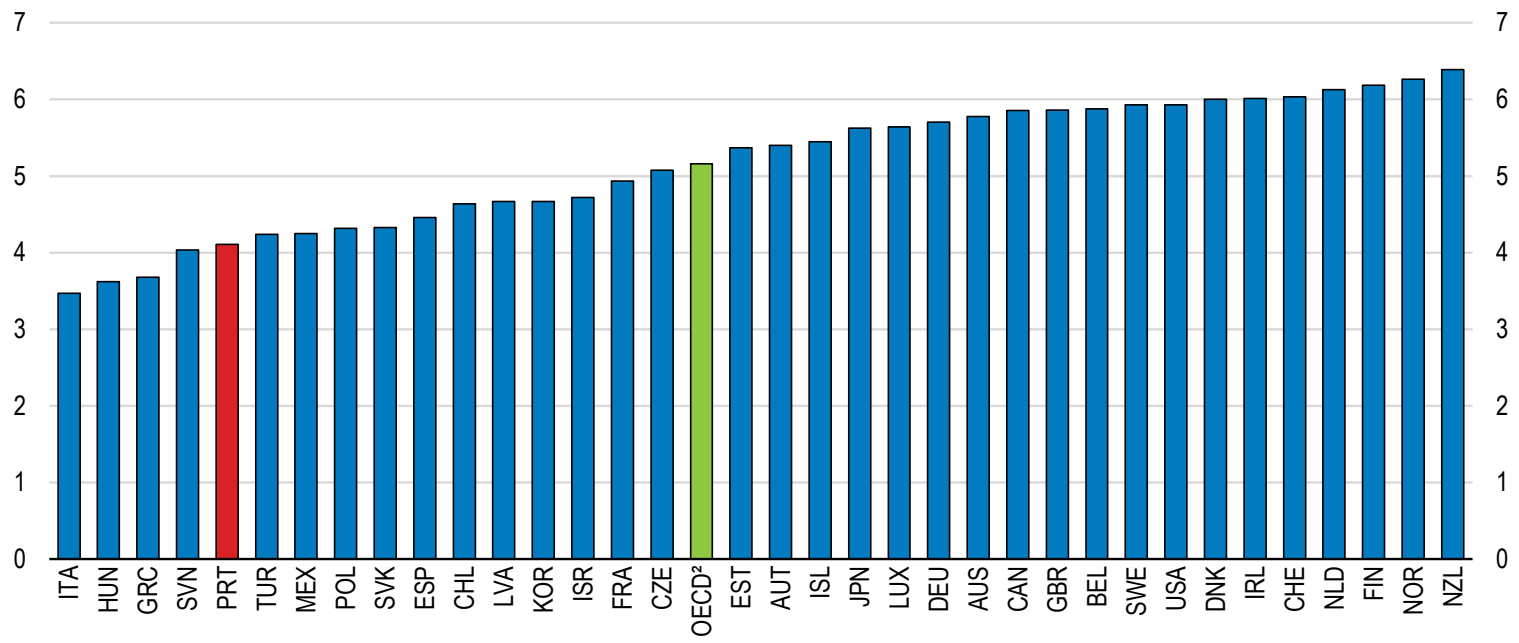

1. Score based on responses to the question: "In your country, who holds senior management positions? [ $1=$ usually relatives or friends without regard to merit; 7 = mostly professional managers chosen for merit and qualifications]".

2. Unweighted average including Latvia.

Source: World Economic Forum (2015), The Global Competitiveness Index Historical Dataset 2006-2015.

Low-skilled managers are likely to reduce returns to investing in ICT as there are important complementarities between managerial capital and ICT capital investment (Brynjolfsson et al., 2000; Bloom et al, 2012). This may also be part of the explanation behind the fact that Portuguese enterprises lag behind international best practice with respect to the use of ICT infrastructures, which also reduces the demand for specialised professionals (Figure 23; OECD, 2014g).

Figure 23. Diffusion of selected ICT tools and activities in enterprises

OECD countries, as a percentage of enterprises with ten or more persons employed, $2014^{1}$

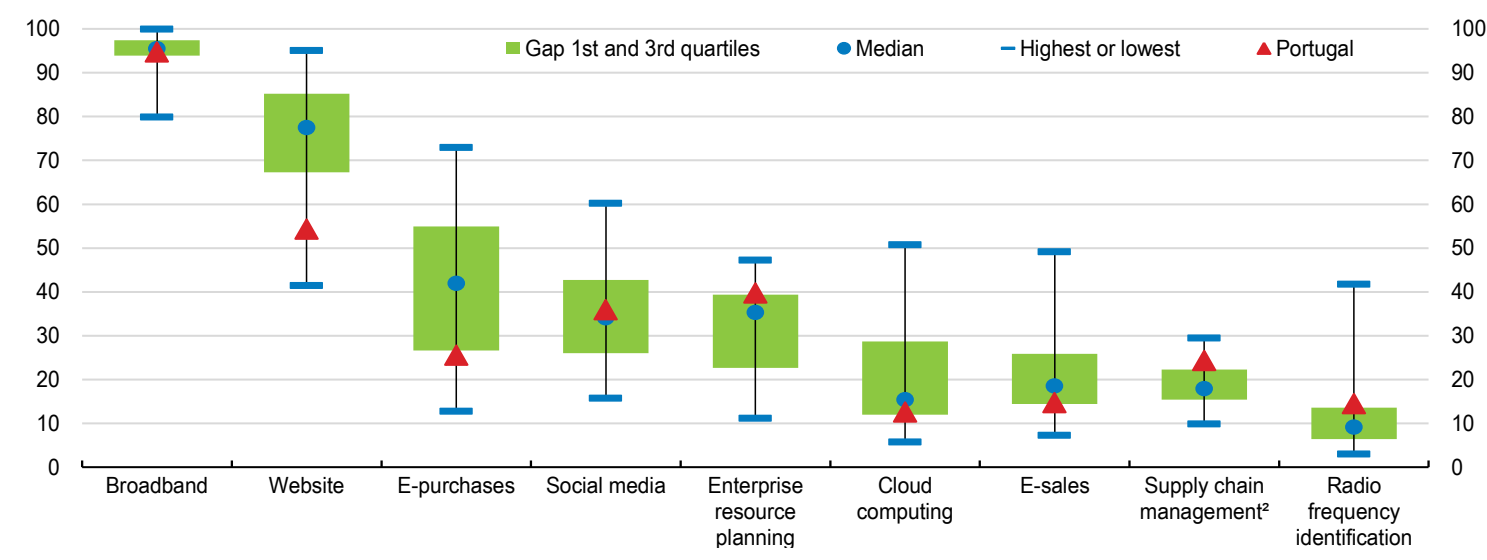

1. Or latest year available. See Indicator 5.2 in the source publication for details of methodology and international comparability. ICT: information and communication technology.

2. Automated data exchange (ADE) applications.

Source: OECD (2015c), OECD Science, Technology and Industry Scoreboard 2015: Innovation for growth and society. 
Providing opportunities for management training for those with management responsibilities but without specific prior training in management is one way forward. Several institutions have developed entrepreneurship training programmes in Portugal but these have often had a strong focus on the initial start-up phase and lacked solid training in business management. Developing management skills, especially in SMEs, should be seen as a priority, as in a number of OECD countries (Box 3). The financial support for training introduced in late 2015 ("Cheque Formação") could also be used to support management training, but given that support is capped at $175 €$ per worker, they are unlikely to make a big difference for managers of SMEs or start-ups wishing to train their staff. A more thorough assessment of the suitability of this scheme for raising managerial skills should be made once more evidence on its uptake becomes available. Complementary to a management skill development programme, Portugal could emulate more specific policies to stimulate the use of high performance workplace practices such as attributing (competitive) grants to assist (targeted) firms with their implementation as in New Zealand and the Netherlands, developing business coaching programmes for SMEs (New Zealand), or supporting the establishment of management and entrepreneurs' networks to disseminate the adoption of good practices as in the Netherlands and Finland (OECD, 2016c, p. 96).

\section{Box 3. Programmes to Enhance Management Skills}

ManagmentWorks was established in 2012 under the Irish government Action Plan for Jobs. It is a management development initiative to help business owners and managers in Ireland to improve business performance through the adoption of higher quality management practices. ManagmentWorks intends to develop expertise in four key areas: business growth, leadership, team management and creating a problem-solving culture. Postgraduate education is also offered in the fields of management, leadership and strategy and innovation, through collaboration with IMI and other, the Irish Management Institute. Individualized business coaching is also provided through a partnership with Action Coach Ireland. ManagmentWorks was developed by Skillnets, a state-funded, enterprise-led body established in 1999 and today's largest provider of workplace training in Ireland through a network of sectoral or regional organized SMEs. The programme is heavily subsidized by the National Training Fund through the Department of Education and Skills.

In 2015 the Chartered Management Institute (CMI) created a degree apprenticeship in management in the UK. The Chartered Manager Degree Apprenticeship was developed jointly by the $\mathrm{CMI}$, a group of large firms and highereducation institutions. The degree will take around four years to complete, during which the apprentice will remain in full-time employment, earning a full time salary throughout the course of their training and studies. Once qualified, workers are expected to be ready to take managerial roles with operational responsibilities. The apprenticeship will be provided by the employer in partnership with a university or business school. It is mostly delivered in the workplace through workplace projects but will also include university study time. Workers who complete the apprenticeship will earn a degree in management and business and become a chartered Manager and member of the Chartered Management Institute, incorporating vocational and academic elements. The program involves government funding of up to two-thirds of the costs.

Sources: ManagementWorks: http://www.managementworks.ie/programmes; accessed on 21 June 2016. The Chartered Manager Degree Apprenticeship: http://www.managers.org.uk/about-us/media-centre/cmi-pressreleases/new-degree-apprenticeship-in-professional-management-given-green-light-by-the-uk-government, accessed on 21 June 2016; https://www.gov.uk/government/publications/apprenticeship-standard-chartered-manager-degreeapprenticeship, accessed on 21 June 2016.

\section{Improve the connectivity between research and business}

Portugal's expenditures on research and development (R\&D) and its performance on various innovation indicators are below the OECD median (see chapter 1 of OECD, 2014a). Moreover, R\&D is mostly concentrated in universities, while business R\&D is particularly low. The low share of business $R \& D$ reflects the fact that a large share of $R \& D$ expenditures occurs in universities, with often weak linkages to industry. The weakness of these links is reflected, for example, in the low number of new hightech firms originating from academia but also in the large number of $\mathrm{PhDs}$ that remain in universities rather than joining the private sector (Figure 24). 
Figure 24. Doctorate holders work primarily in the education sector

As a percentage of all employed doctorate holders, $2012^{1}$

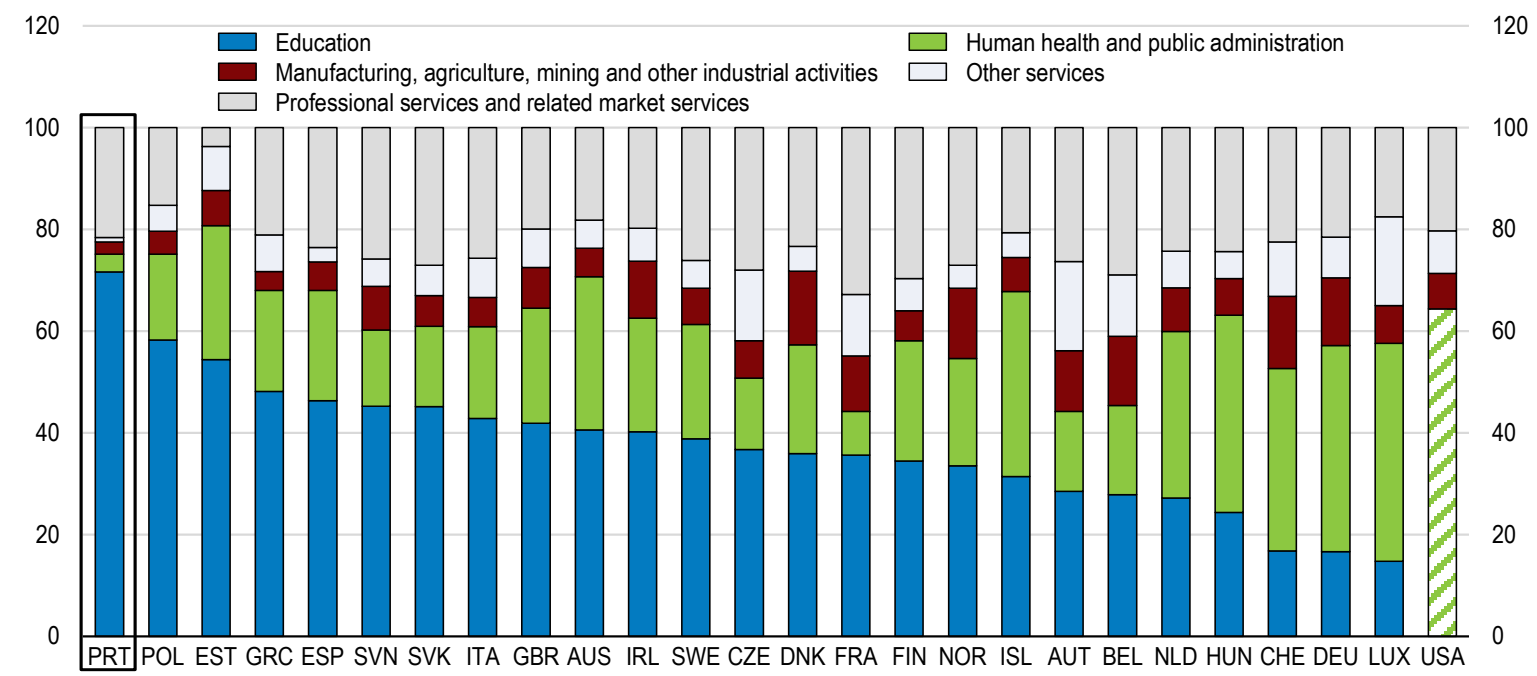

1. 2011 for Australia, 2013 for Germany, Greece, Netherlands and Switzerland. For the United States education is combined with human health and public administration. See Indicator 2.4 in the source publication for further details.

Source: OECD (2015c), OECD Science, Technology and Industry Scoreboard 2015: Innovation for growth and society.

Commercial spin-offs from what were originally academic projects have played an important role for the development of industrial clusters in some countries, notably in the United States where several hightech clusters have emerged around universities and researchers have created important start-up ventures (Capart and Sandelin, 2004; Sandelin 2003; Harayama, 1998). However, only a small share of business in Portugal collaborates with universities or research centres to develop innovation, which limits the commercialisation of knowledge (Figure 25) and the diffusion of technologies, including foreign. Accordingly, the productivity gap between national and global frontier firms tends to be lower in countries where there is more intensive $R \& D$ collaboration between private firms and public research entities (OECD, 2015d).

\section{Figure 25. Only a small share of SMEs collaborates on innovation with higher education or research institutions}

As a percentage of product and/or process-innovating small and medium sized enterprises (SMEs), 2010-12 ${ }^{2}$

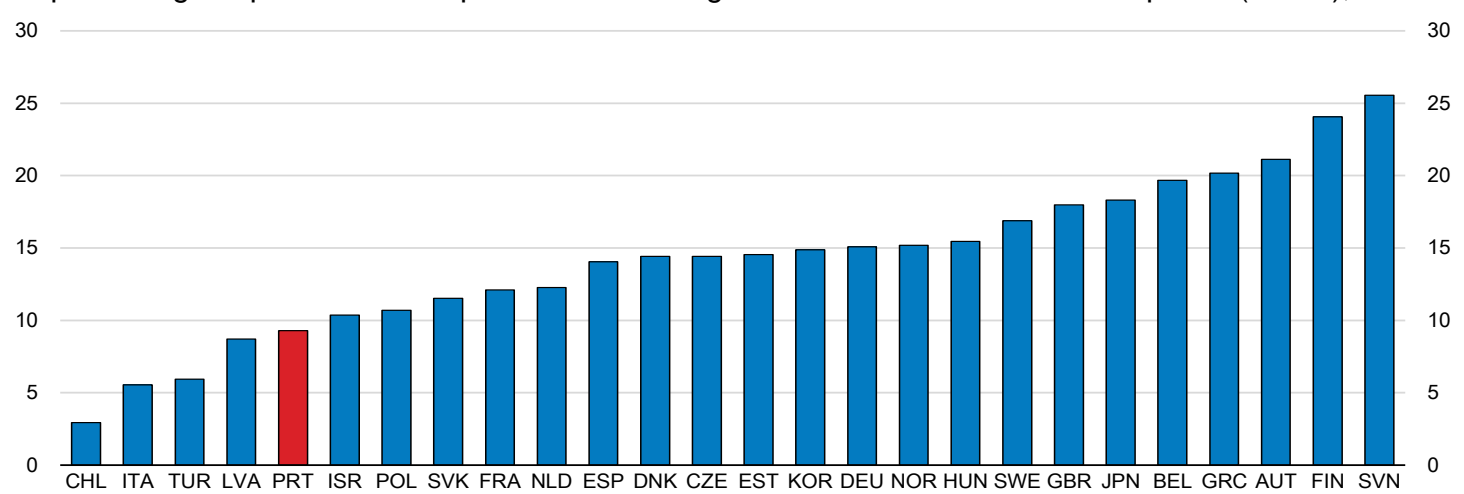

1. International comparability may be limited due to differences in innovation survey methodologies and country-specific response patterns. European countries follow harmonised survey guidelines with the Community Innovation Survey. Please see www.oecd.org/sti/inno-stats.htm and Indicator 3.10 of the source publication for more details.

2. 2011-12 for Chile, 2011-13 for Korea and 2009-12 for Japan.

Source: OECD (2015c), OECD Science, Technology and Industry Scoreboard 2015: Innovation for growth and society. 
Portuguese academics' assessment of the barriers to cooperation between tertiary education institutions and businesses is among the highest in Europe, identifying the low level of funding, excessive red-tape and inadequate university governance as the main culprits (EC, 2016). Cooperation could be facilitated by clarifying and simplifying the rules and procedures governing the cooperation between universities and businesses within the governance structure of tertiary education institutions. Possible avenues to enhance cooperation between academia and the business sector include the creation of a private sector liaison officer with working experience in the private sector and the development of dual careers in tertiary education institutions. Less formal mechanisms could also help building bridges between research and business. These can include running regular seminars with participants from both sectors around specific challenges.

One further area for policy action includes measures to improve the ability of university tech transfer offices (TTOs) to link with industry, inter alia through support for academic patenting. OECD evidence on university technology transfer suggests that the effectiveness of TTOs in linking with business depends on critical mass and expertise, and appropriate organisational structures and incentive schemes. In Portugal, the authorities plan to reinforce the role of innovation centres (Centros de Interface Tecnológico, CIT) which can play such a role. There are about 30 CITs in Portugal; some focus on sector-specific activities of research and innovation, while others have a multi-sector approach. CITs employ about 2740 staff, but less than a fifth are actually PhDs. The recently launched programme capaCITar will raise support for CITs financing, including of high skilled jobs (PhDs). Achieving a critical mass of activities obtaining scale effects in R\&D activities may require merging the activities of some of the CITs, which could also lead to efficiency gains.

\section{Key recommendations}

\section{Main recommendations for raising skills}

- Target life-long learning programmes towards the low-skilled.

- Systematically monitor the outcomes of the different active labour market programmes with a view to concentrating resources on the more effective programmes.

- Progressively reduce grade repetition in primary and secondary education by identifying students at risk early on and developing early individualised support.

- Consolidate the two VET systems into a single dual VET with strong workplace training and perform a thorough audit of all vocational training programmes.

- Strengthen the links between research and the business sector through better incentives for academics to cooperate with industry.

\section{Other recommendations}

- Collect and publish indicators of labour market outcomes (employment, unemployment rates, wage premiums) by level of education and area of study and at the regional level to allow for better-guided education and career choices.

- Ensure adequate coverage of early childhood care across the country, including for children younger than 4 years of age and with a particular focus on those from disadvantaged socio-economic backgrounds.

- Strengthen teacher training and exposure to best practices and enlarge the probationary induction period for beginning teachers.

- Create incentives to attract the most experienced teachers and principals to disadvantaged schools.

- Take better account of students' profiles and specific needs when allocating resources across schools and provide more autonomy to schools to adjust class size accordingly.

- Reduce labour market duality to improve the job quality and strengthen learning incentives.

- Raise managerial skills by developing specific training courses for managers. 


\section{References}

Adalet McGowan, M., D. Andrews, C. Criscuolo and G. Nicoletti (2015), The Future of Productivity, OECD Publishing, Paris, www.oecd.org/eco/growth/OECD-2015-The-future-of-productivitybook.pdf.

Almeida, A. et al. (2016) , "Economic and Non-Economic Returns to Higher Education in Portugal", mimeo, work commissioned by Fundação Francisco Manuel dos Santos, U. Aveiro, U, Minho/NIPE, U. Porto/CIPES.

Almond and Currie (2011), "Human Capital Development before Age Five", Handbook of Labor Economics, Vol. 4, Part B, pp. 1315-1486.

Andrews, D. and B. Westmore (2014), "Managerial Capital and Business R\&D as Enablers of Productivity Convergence", OECD Economics Department Working Papers, No. 1137, OECD Publishing. Paris, http://dx.doi.org/10.1787/5jxx3d441knr-en.

Arnold, J. and C. Farinha Rodrigues (2015), "Reducing Inequality and Poverty in Portugal”, OECD Economics Department Working Papers, No. 1258, OECD Publishing, Paris, http://dx.doi.org/10.1787/5jrw21ng3ts3-en.

Baenen, N. R. (1988), "Perspectives after Five Years - Has grade repetition passed or failed?" communication presented at The Annual Meeting of the American Research Association, New Orleans.

Baptista, J. (2015), Indicadores de Transferência e de Abandono no Ensino Superior Português, presentation at the seminar on "Sucesso Académico"on 12/May/2015, Direção-Geral de Estatísticas da Educação e Ciência, Ministério da Educação.

Bentolila, Samuel, Cahuc, Pierre, Dolado, Juan J., LeBarbanchon, Thomas (2012), "Two-tier labour markets in the great recession: France versus Spain”, Economic Journal, 122, F155-F187.

Bentolila, S., J. Dolado and J. Jimeno (2008), 'Two-tier Employment Protection Reforms: The Spanish Experience', CESifo DICE Report, Ifo Institute for Economic Research at the University of Munich, Vol. 6(4), pp. 49-56, December.

Bloom, N., R. Sadun and J. Van Reenen (2016), "Management as a Technology", NBER Working Papers, No. 22327.

Bloom, N., C. Genakos, R. Sadun and J. Van Reenen (2012), "Management Practices Across Firms and Countries", NBER Working Papers, No 17850.

Boeri, T. (2011), "Institutional Reforms and Dualism in European Labour Markets", Handbook of Labor Economics, Vol. 4, part B, pp. 1173-1236.

Booth, A.; M. Francesconi and J. Frank (2002), “Temporary Jobs: Stepping Stones or Dead Ends?, The Economic Journal, Vol. 112, No. 480, pp. F189-F213. 
Braconier, H., G. Nicoletti and B. Westmore (2014), "Policy Changes for the Next 50 years", OECD Economics Department Policy Papers, No. 9.

Brynjolfsson, E. and A. McAfee (2011), "Race Against The Machine: How the Digital Revolution is Accelerating Innovation, Driving Productivity, and Irreversibly Transforming Employment and the Economy", Digital Frontier Press.

Capart, G. and J. Sandelin (2004), "Models of, and Missions for, Transfer Offices from Public Research Organizations", mimeo, Stanford University, available at http://otl.stanford.edu/documents/JSMissionsModelsPaper-1.pdf, last accessed in September 2016

Carneiro, A., P. Portugal and J. Varejão (2014), "Catastrophic Job Destruction during the Portuguese Economic Crisis”, Journal of Macroeconomics, 39, pp. 444-457.

Carneiro, R. et. al. (2011), Accreditation of prior learning as a lever for lifelong learning: lessons learnt from the New Opportunities Initiative, Portugal, UNESCO, Catholic University Lisbon and MENON (eds), http://www.ucp.pt/site/resources/documents/CEPCEP/Accreditation_final.pdf.

Carneiro, P. and J. Heckman (2003), "Human Capital Policy”, NBER Working Paper No. 9495.

CEDEFOP (2013), Labour Market Outcomes of Vocational Education in Europe: evidence from the European Union labour force survey, Research Paper No. 32, European Centre for the Development of Vocational Training, Greece.

Centeno, M. and A. Novo (2012), "Excess Worker Turnover and Fixed-Term Contracts: causal evidence in a two-tier system", Labour Economics, Vol. 19, n. 3, pp. 320-328.

CIDEC (2004), O Impacto do Reconhecimento do Reconhecimento e Certificação de Compet6encias Adquiridas ao Longo da Vida”, Direção-Geral de Formação Vocacional (DGFV), Lisboa.

CIDEC (2007), O Impacto do Reconhecimento e Certificação de Competências Adquiridas ao Longo da Vida: actualização e aperfeiçoamento, Direção-Geral de Formação Vocacional (DGFV), Lisboa.

CNE (2016), Estado da Educação 2014, Conselho Nacional de Educação, Lisboa.

CNE (2015), Estado da Educação 2013, Conselho Nacional de Educação, Lisboa.

Costa Dias, M. and J. Varejão (2012), Estudo de Avaliação das Políticas Ativas de Emprego: Relatório Final, Faculdade de Economia da Universidade do Porto, Porto, Portugal.

DGEEC (2016), "Desigualdades Socioeconómicas e Resultados Escolares: terceiro ciclo do ensino público geral”, DGEEC - Direção-Geral de Estatísticas da Educação e Ciência, Fevereiro.

Dolado, J., C. Garcia-Serrano and J. Jimeno (2002), 'Drawing Lessons from the Boom of Temporary Jobs in Spain', Economic Journal, Royal Economic Society, Vol. 112, pages F270-F295, June.

Doyle et al (2013), "Measuring Investment in Human Capital Formation: an experimental analysis of early life outcomes", Working Papers 201313, Geary Institute, University College Dublin.

EC (2016), Post-Programme Surveillance Report, Portugal, Winter 2015/2016, European Economy Institucional Paper 022, April 2016. 
European Commission (2014), "Overview of Europe 2020 Targets", http://ec.europa.eu/europe2020/targets/national-targets/index_en.htm.

Eurostat (2016a), “Labour Force Survey Series - Detailed annual survey results”, Eurostat Database.

Eurostat (2016b), "Youth education and training", Eurostat Database.

Eurydice (2016), website accessed on 20 May 2016: https://webgate.ec.europa.eu/fpfis/mwikis/eurydice/index.php/Portugal:Redirect.

EWCS (2015), Eurofound - Sixth European Working Conditions Survey 2015, http://www.eurofound.europa.eu/surveys/2015/sixth-european-working-conditions-survey-2015.

Ferrão, M. E. (2015), "Investigação em Educação e os Resultados do PISA: Análise Estatística da Retenção Através do PISA 2012", Investigação em Educação e os Resultados do PISA, Conselho Nacional de Educação, Dezembro 2015, Lisboa.

Ferrão, M. E., K. I. Beltrão and D. dos Santos ( 2007), O impacto da política de não repetência na proficiência dos alunos da quarta série: um estudo sobre o Sudeste brasileiro. Revista Brasileira de Estatística, vol. 68, n. 229, pp. 69-98.

Ferrão, M. E., K. I. Beltrão and D. dos Santos ( 2002), Políticas de não-repetência e a qualidade da educação: evidências obtidas a partir da modelagem dos dados da 4 a série do SAEB-99. Estudos Em Avaliação Educacional, n. 26, pp. 47-73.

Ferrão, M. E. and C. Fernandes ( 2003), "O Efeito-Escola e a Mudança - Dá para Mudar? Evidências da Investigação Brasileira”, REICE - Revista Eletrônica Iberoamericana sobre Calidad, Eficácia y Cambio em Educación, Vol. 1, n. 1, pp. 1-23.

Ferreira, F. and P. Fernandes (2015), "Fatores que Influenciam o Abandono no Ensino Superior e Iniciativas para a sua Prevenção", Educação, Sociedade \& Culturas, n. 45, pp. 177-197.

Ferro et al (2015a), "Decomposição da Melhoria de Resultados Evidenciados no PISA: Características dos Estudantes versus Sistema Educativo", Investigação em Educação e os Resultados do PISA, Conselho Nacional de Educação, Dezembro 2015, Lisboa.

Guichard, S. and B. Larre (2006), "Enhancing Portugal's Human Capital”, OECD Economics Department Working Papers, No. 505, OECD, Paris. OECD (2006), OECD Economic Surveys: Portugal, OECD Publishing, Paris.

Harayama, Y. (1998), "Private Incentive and the Role of Government in Technology Advancement: Silicon Valley, Stanford University and the Federal Government", mimeo, University of Geneva, available at http://web.stanford.edu/dept/HPS/TimLenoir/SiliconValley99/Harayama/SVResearch.pdf, last accessed in September 2016.

Heckman, J. and P. LaFontaine (2007), "The American High School Graduation Rate: trends and levels", IZA Discussion Papers n. 3216, Institute for the Study of Labor (IZA), Bonn.

Hippach-Schneider, U., M. Krausse and C. Woll (2007), Vocational Education and Training in Germany, Short Description, CEDEFOP Panorama Series, 138, Luxembourg. 
INE (2016), “Average monthly earnings”, Statistical Data, Instituto Nacional de Estatística.

Kuczera, M. (2010), A Learning for Jobs Review of the Czech Republic: 2010, OECD Reviews of Vocational Education and Training, OECD Publishing, Paris.

Lima, F. (coord.) (2012), Os Processos de Reconhecimento, Validação e Certificação de Competências e o Desempenho no Mercado de Trabalho, Centro de Estudos de Gestão, Instituto Superior Técnico.

Lyche, C. S. (2010), "Taking on the Completion Challenge: a literature review on policies to prevent dropout and early school leaving”, OECD Education Working Papers, No. 53, OECD Publishing. http://dx.doi.org/10.1787/5km4m2t59cmr-en.

Manacorda, M. (2012), “The Cost of Grade Retention", Review of Economics and Statistics, Vol. 94, n. 2, pp. 596-606.

Martin, J. (2014), "Activation and Active Labour Markef Policies in OECD Countries: Stylizes Facts and Evidence on their Effectiveness", IZA Policy Paper, No. 84, Bonn.

Martin, J. and D. Grubb (2001), "What works and for whom: a review of OECD countries' experiences with active labour market policies", Institute for Labour Market Policy Evaluation Working Papers No. 14, IFAU.

Nusche, D. et al (2015), OECD Reviews of School Resources: Flemish Community of Belgium 2015, OECD Reviews of School Resources, OECD Publishing, Paris.

http://dx.doi.org/10.1787/9789264247598-en.

OECD (2017), “Taxation and Skills”, OECD Tax Policy Studies, No. 24, forthcoming.

OECD (2016a), Education at a Glance 2016: OECD Indicators, OECD Publishing, Paris, http://dx.doi.org/10.187/eag-2016-en.

OECD (2016b), "GDP per capita and productivity levels", OECD Productivity Statistics database.

OECD (2016c), OECD Employment Outlook 2016, OECD Publishing, Paris. http://dx.doi.org/10.1787/empl_outlook-2016-en.

OECD (2016d), OECD Employment and Labour Market Statistics database.

OECD (2016e), "Taxing Wages: Tax wedge decomposition”, OECD Tax Statistics database.

OECD (2016f), PISA 2015 Results (Volume I): Excelence and Equity in Education, PISA, OECD Publishing, Paris. http://dx.doi.org/10.1787/9789264266490-en

OECD (2016g), Supporting Teacher Professionalism: insights from TALIS 2013, TALIS, OECD Publishing, Paris, http://dx.doi.org/10.1787/9789264248601-en.

OECD (2015a), OECD Skills Strategy Diagnostic Report: Portugal 2015, OECD Publishing, http://www.oecd.org/skills/nationalskillsstrategies/Diagnostic-report-Portugal.pdf.

OECD (2015b), Education at a Glance 2015: OECD Indicators, OECD Publishing, Paris, http://dx.doi.org/10.1787/gov_glance-2015-en. 
OECD (2015c), OECD Science, Technology and Industry Scoreboard 2015: Innovation for growth and society.

OECD (2015d), The Future of Productivity, OECD Publishing, Paris.

OECD (2014a), OECD Economic Surveys: Portugal 2014, OECD Publishing, Paris.

OECD (2014b), PISA 2012 Results: What Students Know and Can Do - Student Performance in Mathematics, Reading and Science, Vol. I, revised edition, February 2014, PISA, OECD Publishing, Paris, http://dx.doi.org/10.1787/9789264201118-en.

OECD (2014c), PISA 2012 Results in Focus, OECD Publishing, Paris, https://www.oecd.org/pisa/keyfindings/pisa-2012-results-overview.pdf.

OECD (2014d), PISA in Focus No. 43: Are disadvantaged students more likely to repeat grades?, http://www.oecd.org/pisa/pisaproducts/pisainfocus/pisa-in-focus-n43-(eng)-final.pdf.

OECD (2014e), Education Policy Outlook: Portugal, OECD Publishing, Paris.

OECD (2014f), Talis 2013 Results: An International Perspective on Teaching and Learning.

OECD (2014g), OECD Science, Technology and Industry Outlook 2014, OECD Publishing, Paris.

OECD (2013a), OECD Skills Outlook 2013: First Results from the Survey of Adult Skills, OECD Publishing, Paris, http://dx.doi.org/10.1787/9789264204256-en.

OECD (2013b), PISA 2012 Results: Excellence through Equity - Giving Every Student the Chance to Succeed, Volume. II, PISA, OECD Publishing, Paris, http://dx.doi.org/10.1787/9789264201132-en.

OECD (2012), Equity and Quality in Education: Supporting Disadvantaged Students and Schools, OECD Publishing, Paris, http://dx.doi.org/10.1787/9789264130852-en.

OECD (2010a), PISA 2009 Results: Overcoming Social Background - Equity in Learning Opportunities and Outcomes, Volume II, OECD Publishing, Paris, http://dx.doi.org/10.1787/9789264091504en.

OECD (2010b), Employment Outlook, Chapter 3: Institutional and Policy Determinants of labour market flows, OECD Publishing, Paris.

OECD (2008), PISA 2006 Vol. 2: Data, OECD Publishing, Paris.

OECD (2006), Improving the Performance of the Education System, OECD Economic Surveys: Portugal, OECD Publishing, Paris.

OECD (2005), Teachers Matter: Attracting, Developing and Retaining Effective Teachers, OECD Publishing, Paris.

OECD (2002), Employment Outlook, Chapter 3: Taking the Measure of Temporary Employment, OECD Publishing, Paris.

Pagani, L. et al (2001), "Effects of grade Retention on Academic Performance and Behavioral Development", Development and Psychopathology, 13, pp. 297-315. 
Pedroso (2011), Análise Prospectiva da Evolução Sectorial em Portugal, http//:angep.gov.pt/default.aspx

PIRLS (2012), International Results in Reading, Boston College, TIMSS \& PIRLS International Study Center

Reis, H. and M. C. Pereira (2015), "Retenção Escolar: evidência dos dados PISA", Investigação em Educação e os resultados do PISA, Conselho Nacional de Educação, Lisboa.

Roderick, M. (1994), "Grade Retention and School Dropout: Investigating the Association", American Educational Research Journal, Vol. 31, No. 4, pp. 729-759.

Roderick, M. and Nagaoka, J. (2005), "Retention under Chicago's High-Stakes testing Program: helpful, harmful, or harmless?", Education Evaluation and Policy Analysis, 27:4, pp. 309-40.

Sandelin, J. (2003), "University Technology Transfer in the U.S.: History, Status and Trends", mimeo, Office of Technology Licensing Stanford University, 2003. Available at:

http://otl.stanford.edu/documents/JSUSHistoryTrends.pdf , last accessed September 2016.

Santiago, P. et al (2012), OECD Reviews of Evaluation and Assessment in Education: Portugal 2012, OECD Publishing, Paris, http://dx.doi.org/10.1787/9789264117020-en.

Schmillen, A. and M. Umkeherer (2013), "The Scars of Youth: effects if early career unemployment on future unemployment experiences", IAB Discussion Papers, No. 6/2013, The Research Institute of the German Federal Employment Agency.

TIMSS 2015 International Results in Mathematics. Retrieved from Boston College, TIMSS \& PIRLS International Study Center website: http://timssandpirls.bc.edu/timss2015/international-results/

World Economic Forum (2015), The Global Competitiveness Index Historical Dataset 2006-2015. 